\title{
Review on Biological Synthesis of Nano-Hydroxyapatite and Its Application in Nano-Medicine
}

\author{
Sabere Nouri ${ }^{1}$, Rasoul Roghanian ${ }^{1 *}$ iD, Giti Emtiazi ${ }^{1}$ iD
}

1. Department of Cell and Molecular Biology and Microbiology, Faculty of Biological Science and Technology, University of Isfahan, Isfahan, Iran

$\underline{10.30699 / i j m m \cdot 15.4 .369}$

\begin{abstract}
Hydroxyapatite (HA) has many applications in medicine, dentistry, diagnosis, drug delivery systems, sewage treatment, bone remodeling, concentrating bacteria, covering implants, and antibacterial activity. Despite the numerous current applications of calcium phosphate compounds, particularly $\mathrm{HA}$, their producing methods are being investigated to find the best processes. Several chemical and biological methods are used in calcium phosphate compounds synthesis. Researches have shown that compared to micrometer models, nanostructured HA has higher mechanical features and better biocompatibility in the human body. These properties optimize when nanometer components of HA are in similar size and shape with the least agglomerations. Biomineralization by microorganisms, which is a bacterial route, is a recent HA synthesis method. This paper is a review on the biosynthesis of HA emphasizing microbial methods. In this method, some bacteria and mold could be used in the nanometer production of HA. This type of bacterium commonly has a high amount of alkaline phosphatase enzymes. Desirable similarity to natural HA in the human body is the noticeable features of bacterial HA. Uniformity in the shape and size of synthesized particles that have the same crystallization is of other merits. Producing bacterial HA is easily reachable, one-step, inexpensive, harmless, and with high purity, and contrary to chemical synthesis, does not need heat treatment and precise $\mathrm{pH}$ adjustment.
\end{abstract}

Keywords: Nanostructure, Hydroxyapatite, Alkaline phosphatase, Biomineralization

Received: 2021/03/02; Accepted: 2021/07/11; Published Online: 2021/08/16

\begin{tabular}{cl}
\hline Corresponding Information: & $\begin{array}{l}\text { Rasoul Roghanian, , Department of Cell and Molecular Biology and Microbiology, Faculty of Biological Science and Technology, } \\
\text { University of Isfahan, Isfahan, Iran. } \\
\text { Email: rasoul roghanian @yahoo.co.uk }\end{array}$ \\
\hline Ca) & Copyright (C) 2021, This is an original open-access article distributed under the terms of the Creative Commons Attribution-noncommercial 4.0 International License which \\
permits copy and redistribution of the material just in noncommercial usages with proper citation.
\end{tabular}

Use your device to scan and read the article online

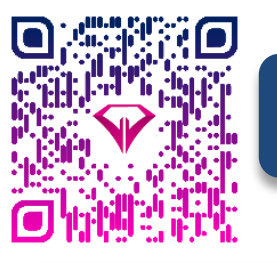

Nouri S, Roghanian R, Emtiazi G. Review on Biological Synthesis of Nano-Hydroxyapatite and Its Application in Nano-Medicine. Iran J Med Microbiol. 2021; 15 (4) :369-383

Download citation: BibTeX | RIS | EndNote | Medlars | ProCite | Reference Manager | RefWorks

Send citation to: $8 \underline{\text { Mendeley }} 2$ zotero $\overline{\text { RefWorks }}$

\section{Introduction}

Hydroxyapatite (HA) is one of the most important bioceramics utilized in medicine, and it has been intensively explored in recent years. It has a chemical composition and structure that is remarkably similar to bone and teeth minerals. After being implanted in the body, this bioactive and biocompatible substance interacts well with bone tissue and forms a direct bond with it $(1,2)$. HA binds, grows, and stimulates the synthesis of new bone tissue and stimulates bone growth into its porous space. This compound has the bone tendency, doesn't absorb and decompose, and ultimately achieves good adhesion to bone tissue (3, 2). Therefore, due to the compatibility of HA with bone tissue and soft tissues, this substance is the best substitute for hard tissues of the body such as bones and teeth. Generally, HA forms up $70 \%$ of human hard tissue as a mineral phase. The term "apatite" refers to a group of compounds that are structurally similar but 
not chemically identical. As a result, the term apatite refers to a description rather than a substance $(4,2)$.

\section{Materials and Methods}

The current study is a review, and all sources were gathered and retrieved from authentic databases in English. The search was conducted using the keywords nano, hydroxyapatite, biological synthesis, nanobiotechnology, and microorganisms on Google Scholar, Science Direct, and PubMed. It should also be noted that this research is based on articles published by the corresponding authors, Dr. Giti Emtiazi and Dr. Rasoul Roghnian.

\section{Results}

\section{1- Properties and crystallography of HA}

The apatite family is crystallized by the arrangement of a hexagonal prism with parallelograms. HA also ideally has a hexagonal structure with dimensions of 2 x 30 x $50 \mathrm{~nm}$ and has a specific composition of $\mathrm{Ca}_{10}$ $\left(\mathrm{HPO}_{4}\right)_{6}(\mathrm{OH})_{2}$ and a definite crystallographic structure. The chemical composition of pure hydroxyapatite is as follows: 39.68 percent calcium, 18.45 percent phosphorus, with a weight ratio of calcium to phosphorus of 2.151 and a molar ratio of calcium to phosphorus of 1.67. (5).

HA has a complex and relatively large single cell in which the integrity is likely to be lost. When the atomic ratio of calcium to phosphorus in hydroxyapatite is 1.6 , it is totally stoichiometric. Therefore, due to the possibility of changes in the structure and its composition, which leads to the formation of nonstoichiometric HAs. Phosphate ions, calcium ions, and hydroxyl groups in HA can be replaced by other ions. These changes have a special effect on physical properties, crystal structure, the molar ratio of calcium to phosphorus, and the solubility of HA under physiological conditions $(1,2)$. Although it is insoluble in water, this substance is regarded as a degradable material (with slow disintegration rate) (6).

\section{2- Applications of HA}

The main applications of HA in medicine, dentistry, diagnostics, catalysis, and sewage treatment are briefly outlined here. Direct application in orthopaedics (7), bone tissue engineering (8), implant coating (9), antibacterial effect (10), drug delivery systems (11, 12), and application in dentistry (15) are some medical applications.

In general, bone tissue can self-repair; however, in cases such as serious bone tissue damage and aging, the bone's ability to self-repair is eliminated. The researchers then introduced $\mathrm{HA}$ for replacement in bone tissue. Because of HA's biocompatibility and bioactivity, it can drive the growth of bone cells into its porous space, resulting in bone cell differentiation and proliferation. Therefore, this material is used in bone tissue engineering and bone cement engineering. Therefore, HA has made significant progress in orthopedics and the placement of implants and bone grafts. HA is also used in oral and maxillofacial implants to increase the height of decayed gums that are unable to mount dentures and implant grafts. Tooth enamel caries can also be partially regenerated using HA toothpaste, according to studies. Because HA has a high affinity for biological substances, it can lead to successful transplantation by replacing drugs, especiaIly antibiotics and immunosuppressive drugs, in implants coated with HA $(7-12,15)$.

Other applications such as non-medical included bacterial concentration (13), removal of radioactive metals (14), use in biosensors (16), and the use of HA as a catalyst (17).

\section{3- Methods of synthesis of HA}

Although calcium phosphate compounds had a wide range of uses in recent years, the optimal production methods are still being researched, particularly in the case of HA. Numerous chemical and biological methods are used to synthesize this substance, as follows (1).

\section{3-1- Chemical synthesis of HA}

Nowadays, various chemical methods are used to produce HA nanocrystals, which depending on the type of method, produce products with different structures, appearance, and crystalline characteristics. Generally, chemical methods for the synthesis of HA can be divided into two categories: wet chemical synthesis methods and dry chemical synthesis methods (18). Dry synthesis methods or anhydrous mechanical synthesis methods include solid-state reaction and mechano-chemical reaction (19).

Considering raw materials, wet chemical reactions, including acid-base method, sol-gel method, ultrasonic-chemical synthesis, microwave synthesis reaction, multiple emulsion technique using templates or micelles, chemical deposition technique, preparation method using conversion hydrothermal and soluble ignition method. These methods usually use soluble salts such as calcium nitrate and calcium chloride, ammonium dihydrogen phosphate or diammonium hydrogen phosphate, and potassium phosphate. Table 1 summarizes the chemical synthesis methods of HA. $(1,19)$. 


\begin{tabular}{|c|c|c|c|c|c|c|}
\hline & Method & Precursors & $\begin{array}{l}\text { Conditions and } \\
\text { mechanisms of } \\
\text { synthesis }\end{array}$ & Size & Morphology & Crystallinity \\
\hline \multirow{2}{*}{$\begin{array}{c}\text { Dry } \\
\text { synthesis }\end{array}$} & Solid-state & $\begin{array}{c}\mathrm{CaCO}_{3} \\
\mathrm{CaHPO}_{4} \cdot 2 \mathrm{H}_{2} \mathrm{O}\end{array}$ & $\begin{array}{l}\text { Temperatures } \\
\text { above c1000 }\end{array}$ & $\begin{array}{l}\text { More than } \\
500 \mathrm{~nm}\end{array}$ & variable & Almost high \\
\hline & Mechano-chemical & $\begin{array}{c}\mathrm{CaO} \\
\mathrm{CaHPO}_{4}\end{array}$ & $\begin{array}{l}\text { Mill with speed } \\
\text { above 600rmp }\end{array}$ & $\begin{array}{l}\text { More than } \\
200 \mathrm{~nm}\end{array}$ & Variable & Almost high \\
\hline \multirow{8}{*}{$\begin{array}{c}\text { Wet } \\
\text { synthesis }\end{array}$} & Acid-base & $\begin{array}{c}\mathrm{Ca}(\mathrm{OH})_{2} \\
\mathrm{H}_{3} \mathrm{PO}_{4}\end{array}$ & $\begin{array}{l}\text { Reaction between } \\
\text { acid and base }\end{array}$ & Micron & Variable & Low \\
\hline & Sol-ge & $\begin{array}{c}\text { Urea } \\
\text { EDTA } \\
\mathrm{Ca}\left(\mathrm{NO}_{3}\right)_{2} \\
\mathrm{NH}_{2} \mathrm{PO}_{4}\end{array}$ & $\begin{array}{l}\text { Molecular mixing } \\
\text { of calcium and } \\
\text { phosphorus in a } \\
\text { jelly-like } \\
\text { atmosphere }\end{array}$ & Nano & $\begin{array}{l}\text { Generally } \\
\text { spherical }\end{array}$ & Almost high \\
\hline & Ultrasonic-chemical & $\begin{array}{c}\mathrm{Ca}(\mathrm{OH})_{2} \\
\mathrm{H}_{3} \mathrm{PO}_{4} \\
\mathrm{Ca}\left(\mathrm{CH}_{3} \mathrm{CO}\right)_{2} \\
\mathrm{PO}(\mathrm{OCH})_{3}\end{array}$ & $\begin{array}{c}\text { Create bubbles, } \\
\text { burst bubbles and } \\
\text { collide raw } \\
\text { materials }\end{array}$ & $\begin{array}{l}\text { Nano and } \\
\text { micron }\end{array}$ & $\begin{array}{c}\text { Generally } \\
\text { needles like }\end{array}$ & Almost low \\
\hline & Microwave & $\begin{array}{c}\mathrm{Ca} \\
\mathrm{PO}_{4}\end{array}$ & $\begin{array}{c}\text { Heat and radiation } \\
\text { waves }\end{array}$ & Micron & Variable & Almost low \\
\hline & Multiple emulsion & $\begin{array}{c}\mathrm{Ca} \\
\mathrm{PO}_{4}\end{array}$ & $\begin{array}{l}\text { Dissolve the } \\
\text { reactant in water } \\
\text { and emulsify water } \\
\text { in oil }\end{array}$ & $\begin{array}{l}\text { Nano and } \\
\text { micron }\end{array}$ & $\begin{array}{l}\text { Generally } \\
\text { spherical }\end{array}$ & Almost low \\
\hline & $\begin{array}{l}\text { Chemical } \\
\text { deposition }\end{array}$ & $\begin{array}{c}\mathrm{Ca}\left(\mathrm{NO}_{3}\right)_{2} \\
\left(\mathrm{NH}_{4}\right)_{3} \mathrm{HPO}_{4}\end{array}$ & Sedimentation & Micron & Variable & Low \\
\hline & $\begin{array}{l}\text { Conversion } \\
\text { hydrothermal }\end{array}$ & $\begin{array}{c}\mathrm{Ca} \\
\mathrm{PO}_{4}\end{array}$ & $\begin{array}{l}\text { High pressure, high } \\
\text { temperature }\end{array}$ & Micron & $\begin{array}{c}\text { Variable } \\
\text { (Generally } \\
\text { dandelion like) }\end{array}$ & Almost low \\
\hline & Soluble ignition & $\begin{array}{l}\mathrm{NH}_{2} \mathrm{PO}_{4} \\
\mathrm{Ca}\left(\mathrm{NO}_{3}\right)_{2}\end{array}$ & $\begin{array}{l}\text { Add oxidizing } \\
\text { agents }\end{array}$ & $\begin{array}{l}\text { Nano and } \\
\text { micron }\end{array}$ & $\begin{array}{c}\text { Variable } \\
\text { (Generally } \\
\text { needles like) }\end{array}$ & Almost low \\
\hline
\end{tabular}

According to the findings of Hsieh et al., the sol-gel method has advantages over the other chemical methods listed in Table 1. This method requires lowtemperature treatment compared to other methods. Because chemical methods usually use very high temperatures to form crystals. However, the temperature required for the HA formation operation in the sol-gel method is much lower. It is more cost-effective than others, and compared to the products of other methods, the HA synthesized from this method has a unique form. It is also possible to achieve nano size in this method. Another advantage of sol-gel compared to other chemical methods is the ability of this method to synthesize HA nanoparticles with almost higher purity (40).

\section{3-2- Biological synthesis of HA}

The bone tissue of most mammals, poultry, and fish is a major source of HA. This type of HA, as opposed to its synthetic type, is called biological or natural $\mathrm{HA}$. Other sources of natural HA include coral, shrimp shells, snakeskin, hedgehog thorns, and some plants and algae. One of the most common sources of natural $\mathrm{HA}$ is mammalian bones such as livestock. This compound is obtained during long heat treatment at temperatures of about 1000 degrees Celsius. One of the major advantages of natural HA over chemical HA is that its physical structure and chemical makeup are identical to that of human bone tissue. For bioceramics like $\mathrm{HA}$, the presence of a porous struc-ture with appropriate porosity is highly desirable, and the natural kind of HA provides this porous structure. The chemical composition also greatly affects the performance of HA. Large crystal bridges and large amounts of calcium oxide result in lower biocompatibility of $\mathrm{HA}$. Components from the decomposition of $\mathrm{HA}$ also cause $\mathrm{pH}$ changes around the planting site. The benefits of natural HA include the presence of trace elements in bone tissue. Elements such as magnesium, sodium, potassium, iron, zinc, and other similar elements are present in very small amounts in bone tissue and play an important role in the process of bone repair and regeneration. Another significant advantage of natural $\mathrm{HA}$ is its relatively inexpensive and cost-effective process $(20,21)$.

\section{3-2-1- Bacterial Synthesis of HA}

One of the new methods of synthesis of nanosized and natural HA is the microbial method or biomineralization method by microorganisms. As Emtiazi et al. previously proved that the bacterium can produce copper oxide and zinc oxide nanoparticles and listed many properties such as antibacterial properties for them, we decided that microorganism should be studied as a factory for the production of other nanoparticles (22-26). 


\section{3-2-1-1- The role of Phosphatase Enzyme in the Formation of HA}

Biomineralization is the process through which $\mathrm{HA}$ settles in the extracellular matrix during the osteogenesis process. Physiological mineralization occurs in hard tissue while calcification occurs in soft tissue. Tissue non-specific alkaline phosphatase (TNAP) hydrolyzes pyrophosphate and supplies inorganic phosphate to promote mineralization. This enzyme is also present in the bacterium and the process mentioned in this microbe is also possible (28).

Generally, there are two types of phosphatase enzymes in microorganisms. Generally, Acid phosphatase is outside the bacterial membrane, and Alkaline phosphatase is located in the periplasmic region of the bacterial membrane $(27,29)$. Acid phosphatase enzymes can be used to make HA, although nanometersized HA crystals are larger since these enzymes are extracellular. Furthermore, the optimal $\mathrm{pH}$ for the activity of acidic phosphatase enzymes is below 5.8, at which point $\mathrm{HA}$ is demineralized and eliminated, albeit with the use of bacteria in the pericardial region that contains alkaline phosphatase. However, by using bacteria that have a high level of alkaline phosphatase in the periplasmic region and controlling the conditions, nanometer dimensions of HA with biocompatibility and bioactivity properties can be achieved. The optimum $\mathrm{pH}$ for the activity of alkaline phosphatase enzymes is $9(4,30)$.

All alkaline phosphatase enzymes belong to the hydrolase enzymes group, which nonspecifically tran- sfer phosphate groups from all phosphomonoester compounds [R-O-PO $]_{n}$ to hydroxyl-containing polyamines $(\mathrm{OH})$ such as ethanolamines. In the structure of these metalloenzymes, there are two protein monomeric chains, two active zinc nuclei, and two cofactor sites for magnesium and calcium (Figure 1).

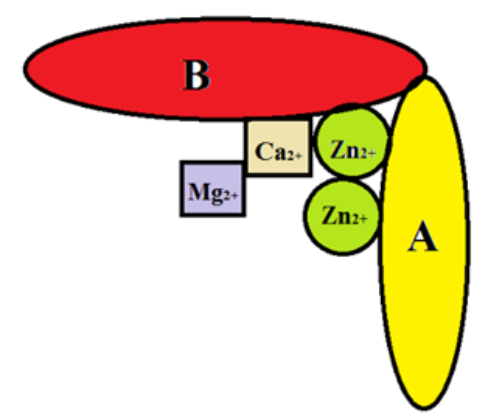

Figure 1. Schematic picture of alkaline phosphatase metaloenzyme. A and B: protein monomeric chain, $\mathrm{Zn}^{2+}$ : active site of zinc, $\mathrm{Mg}^{2+}$ and $\mathrm{Ca}^{2+}$ : cofactor site for magnesium and calcium. (Source: Authors)

The function of these enzymes can be described as follows: first, they release phosphate groups from phosphomonoester compounds. Then offer phosphate groups to hydroxyl in the limited periplasmic space. In the next step, cation attachment of $\mathrm{Zn}, \mathrm{Mg}$, and Ca will complete the nano crystallin HA synthesis.
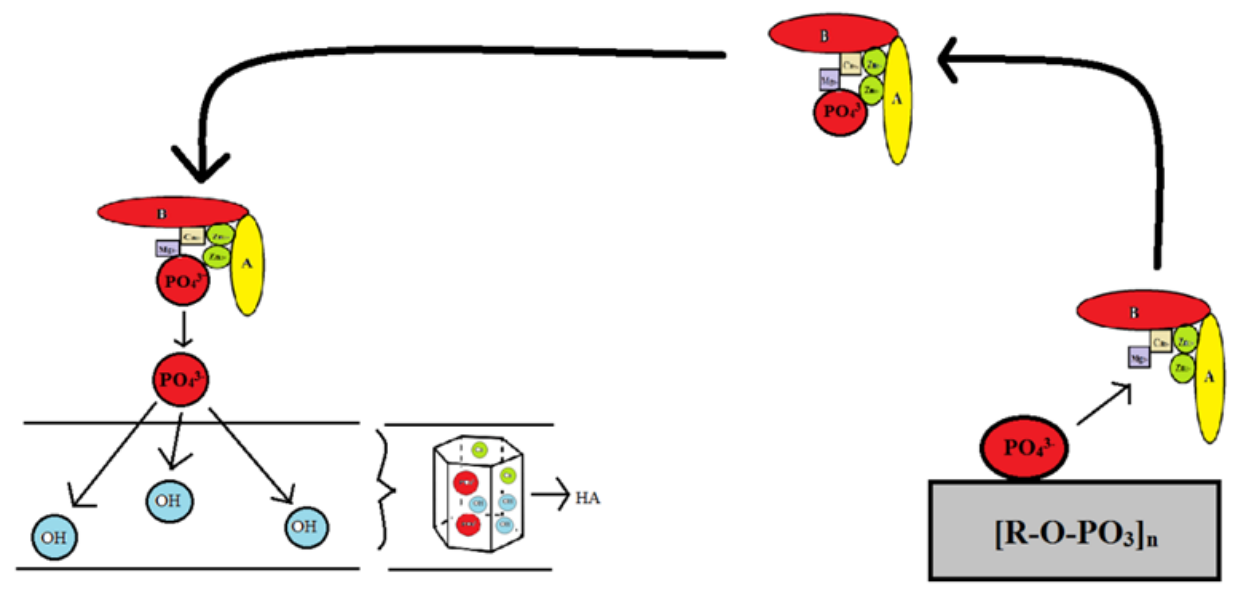

Figure 2. Expected process of HA crystals formation in bacteria and the role of alkaline phosphatase enzyme in this process. (Source: Authors)

Some gram-negative bacteria contain a group of alkaline phosphatase enzymes that can be hydroxylated by using these bacteria and adding simple phosphomonoester compounds such as glycerol-2phosphate, using an alcohol receptor such as Tris, and by adding calcium ions, synthesized nanometer apatite in the bacterial periplasmic space. This spatial constraint plays a key role in the formation of HA in the form of hexagonal prisms and nanometer crystal clusters (32). 


\section{3-2-1-2- The role of urease enzyme in the formation of HA}

The enzyme urease is widely found in bacteria and is often used to produce microbial calcite. There are four regulatory models for the synthesis of urease enzymes in the microbial system. Constitutive urease is expressed steadily and independent of external conditions in the cell. Inducible urease is induced by an inducing molecule such as urea or other environmental conditions. Repressible urease is suppressed in the presence of ammonia, which is removed under nitrogen restriction and enzymatic activity is increased. Finally, developmental urease means that the organism expresses a variable expression of urease in different evolutionary stages $(33,34)$.

Most microorganisms, with their ability to break down urea, use it as a source of nitrogen that is transported into the cellular cytoplasm by active transfer or inactive diffusion, where hydrolysis of urea releases ammonia molecules. Ammonia can then be absorbed directly by the glutamine synthetase-glutamate synthase pathway or by the action of glutamate dehydrogenase. An ideal microorganism for biocementation should be resistant to high concentrations of urea and calcium. This microorganism often has to have a high level of urease activity that is permanently produced or can be significantly induced. Urease-producing bacteria are divided into two groups based on their response to ammonia. There is a group in which the enzyme activity is not suppressed in the presence of ammonia and a group in which the urease activity is suppressed $(34,35)$.
In the synthesis of urease $\mathrm{HA}$, different amounts of $\mathrm{CaCl}_{2}$ and $\mathrm{NaH}_{2} \mathrm{PO}_{4}$ are used, in which case the decomposition of urea by urease causes homogeneous deposition of $\mathrm{HA}$, due to the release of $\mathrm{OH}$ ions during the process of hydrolysis of urea. The carbonate ions formed in these reactions can also enter the crystal structure of HA particles. Thus, a type of carbonate HA is formed that may have a very similar structure to apatite in human bones. The experimental results show that reducing the ratio of material concentration to urease concentration reduces the particle size to less than $100 \mathrm{~nm}$ and their morphology changes to a spherical shape. One of the advantages of urease enzyme in the formation of HA is that the presence of urease allows the decomposition of urea at a lower temperature and the enzyme is not consumed during the reaction (36).

\section{3-2-2- Fungal synthesis of HA}

In the results of HA experiments, it has been observed that some fungi such as Aspergillus niger have the ability to stimulate the synthesis of HA in Potato Dextrose Agar (PDA) medium with appropriate concentrations of substances such as $\mathrm{Na}_{2} \mathrm{HPO}_{4}$ and $\mathrm{CaCO}_{3}$, which are the main cause of $\mathrm{HA}$ crystals formation. Fungal metabolism produces an acidic subst-ance to dissolve $\mathrm{CaCo}$, and the growth of micelles causes the uptake of $\mathrm{Ca}^{2+}$, which leads to calcium-rich levels to promote the production of secondary apatite, which is eventually converted to HA (Figure 3) (37).

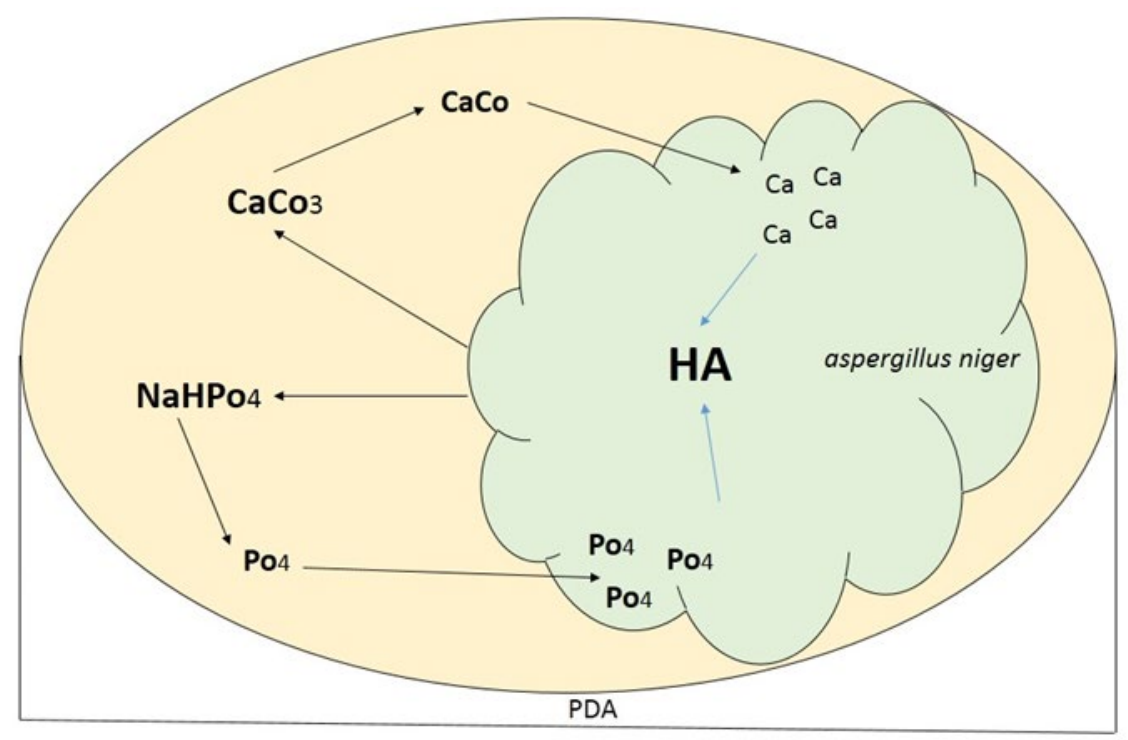

Figure 3. Predicted trend for HA formation in micelles and fungal hyphae (Source: Authors) 
Alternatively, Aspergillus niger and wheat bran (as a source of phosphorus) have been used for the synthesis of HA. Wheat bran contains a significant amount of phosphorus (in the form of phytic acid), which is considered a cheap agricultural waste. This reaction is performed by using an extracellular phytase enzyme produced by fermentation of wheat bran with the mentioned fungus. Phytase is a class of phosphohydrolases that catalyzes the hydrolysis of phytic acid to the mineral monophosphate. Finally, calcium chloride is added to the fermented mushroom and wheat bran mixture, which a white precipitate is observed in the mixture after $24 \mathrm{~h}$. Following the identification procedures, HA with characteristics similar to human bone HA was discovered. Nanostructured $\mathrm{HA}$ is naturally the major component of bone and teeth in humans

\section{Conclusion}

HA has been produced for bone tissue engineering, implant coating, bone cement engineering, drug delivery systems, and other medical and non-medical uses in recent decades using different chemical and biological methods. Various chemical approaches have been proposed for the production of HA up to this point. According to the results and studies, the sol-gel approach is more suitable than other methods in the chemical synthesis of HA (1, 39 - 41). Generally, chemical methods have disadvantages compared to biological and natural approaches. These disadvantages included the need for precise $\mathrm{pH}$ adjustment, the lack of biocompatibility, the high cost of raw materials, and finally that it is not possible to achieve high purity of crystallinity and uniformity in shape and size. On the other hand, microbial HA size is between 25 and 30 nanometers (which is very close to natural HA in the human body). This subject draws the attention of scientists to the synthesis of microbial HA. The size and shape of the produced particles are homogeneous and have appropriate crystallinity in microbial synthesis, which improves the material's biocompatibility and bioactivity while also contributing to the mechanical qualities of the final HA part. Production of microbial HA is one-step, inexpensive, non-toxic, and has high purity. Unlike chemical synthesis, it does not require temperature treatment and precise $\mathrm{pH}$ adjustment and is easily achievable. Also, the antibacterial properties of these particles are very significant. However, with these interpretations, microbial synthesis of HA on a large scale is not possi- ble as much as chemical synthesis. However, because bone cell differentiation does not necessitate a large amount of $\mathrm{HA}$, this kind of $\mathrm{HA}$ can be used in cell differentiation $(1,27,42,43)$.

Microbial HA in animal in-vivo experiments has shown the ability of osteogeneration and degradability than chemically synthesized samples. Due to this property, in addition to cost-effectiveness, it is possible to achieve more suitable HA for medical purposes by developing a microbial approach.

Bio-nano-HA can play an important role as a revolution in nanomedicine. Bone injuries in modern life and the risk of rejection of bone implants have led scientists to discover new materials to improve bone repair, and scientists have turned to life sciences to build alternatives to bone grafts. Due to the morphological similarity of biological HA with natural HA and its dimensional similarity (at the nanoscale), significant application of this material is expected in the nanomedical industry, bone tissue engineering, and bone cement engineering. The use of engineering principles in the creation of tools to study, modify, and produce tissue from natural or synthetic sources is known as bone tissue engineering. The primary goal of this approach is tissue regeneration and organ function improvement through the use of three-dimensional HA scaffolds. Cells from the patient's body (or human or animal transplant cells) or bone marrow are implanted into these scaffolds, which are then implanted in the patient's body. These scaffolds need to be as similar as possible to bone tissue. The engineering of bone cements is also created as a filler for cavities and bone defects, the most important of which is nano-HA (7). Biological nano-HA is used to make composites, dental filling cement, and oral and maxillaofacial implants. It was offered as a substance to prevent the formation of dental enamel decay and its partial restoration in the form of nano-HA toothpaste. There have also been reports of this bacterial bio cement used in the laboratory to repair rabbit jaw bone $(15,4)$.

\section{Acknowledgment}

None

\section{Conflict of Interest}

The authors did not report any conflict of interest. 


$$
\begin{aligned}
& \text { مجله ميكروبشناسى يزشكى ايران } \\
& \text { سال ها ـ شماره F ـ هامرداد و شهريور “. } \\
& \text { Journal homepage: www.ijmm.ir }
\end{aligned}
$$

مرورى بر مكانيسم سنتز بيولوزيكى نانوذرات هيدروكسى آياتيت و كاربرد آن در نانويزشكى

\title{
صابره نورى، رسول روغنيان"(D). كيتى امتيازى (1)
}

\author{
كروه زيست شناسى سلولى ملكولى و ميكروبيولوزى، دانشكده علوم و فناورى هاى زيستى، دانشكاه اصفهان، اصفهان، ايران.
}

\section{جكيله}

هيدروكسى آياتيت كاربردهاى فراوانى در زمينههاى يزشكى، دندانيزشكى، تشخيصى، سيستمهاى رهايش رهايش دارو، تصفيه

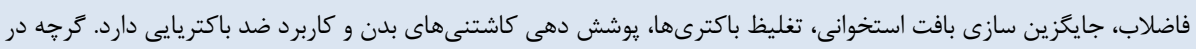

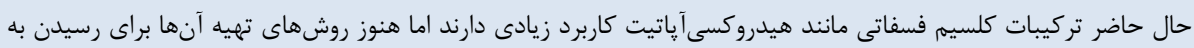

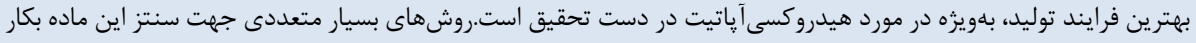

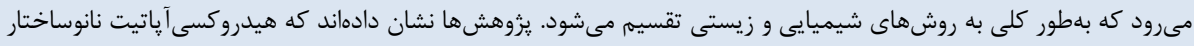

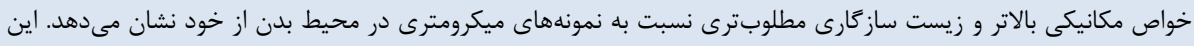

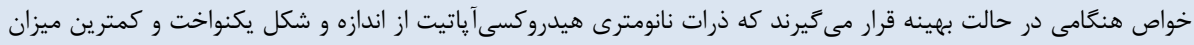

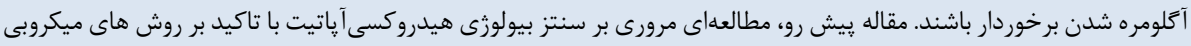

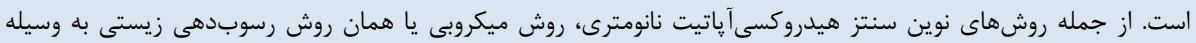

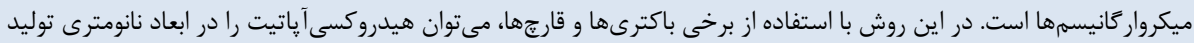

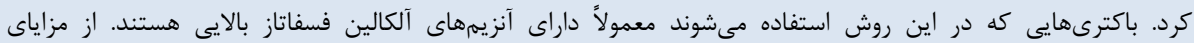

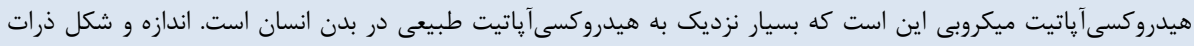

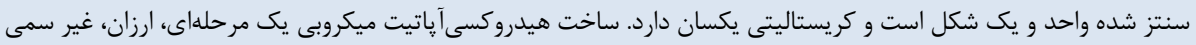

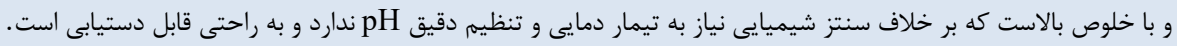

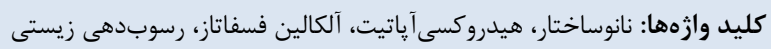

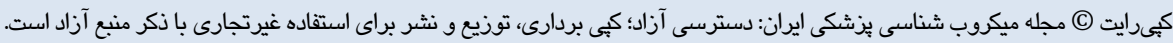

اطلاعات مقاله

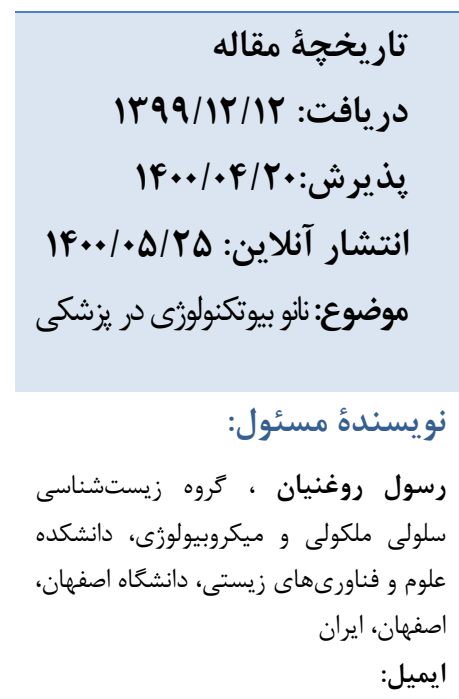

$\underline{\text { rasoul_roghanian@yahoo.co.uk }}$

مقدمه

استخوان و بافتهاى نرم، اين ماده بهترين جانشين براى بافتهاى

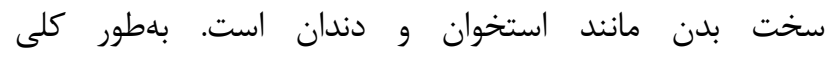

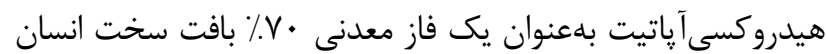

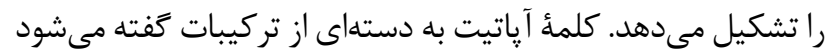
كه ساختارى مشابه دارند ولى حتما تركيب يكسانى نخواهند داشت.

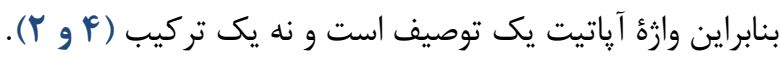

$$
\text { مواد و روشها }
$$

مطالعة حاضر از نوع مرورى بوده و تمامى منابع مورد استفاده از

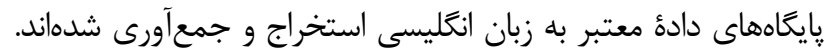
اين جست و جو با استفاده از كلمات كليدى نانو، هيدروكسى آياتياتيت،

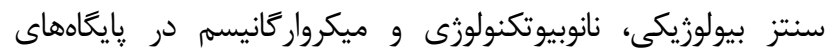

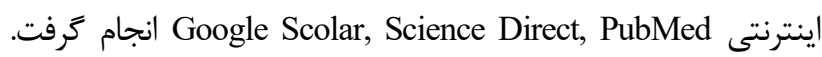

از مههمترين سراميكهاى زيستى مورد استفاده در يزشكى كه

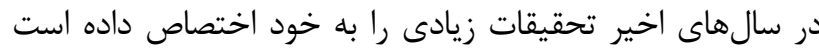

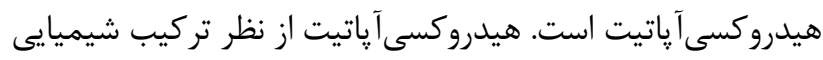

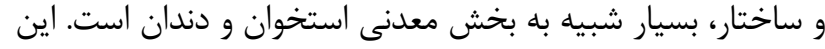

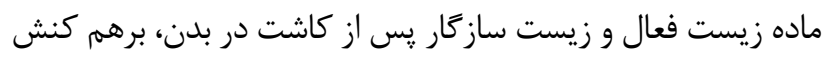

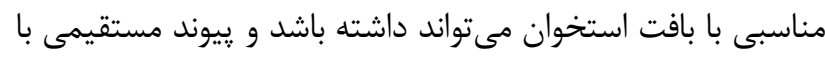

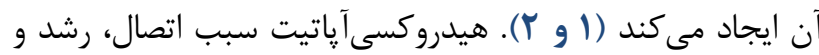
تحريك سنتز بافت استخوانى جديد مىشود و رشد استخوان را به إنه درون فضاى متخلخل خود تحريك مى كند. اين تركيب استخوان

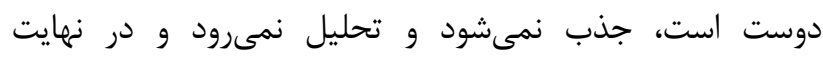

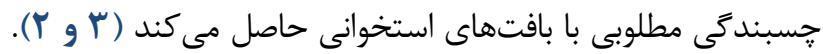

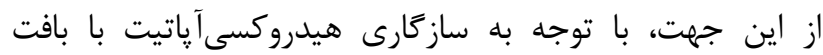


باطور كلى بافت اسنخوان توانايى خود ترميمى دارد، اما مواردى از جمله آسيب جدى به بافت استخوان و كهولت سن،

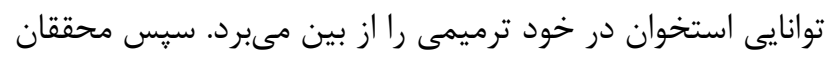

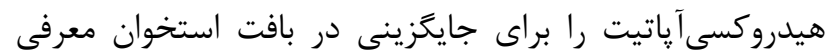

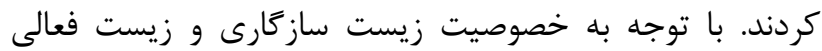

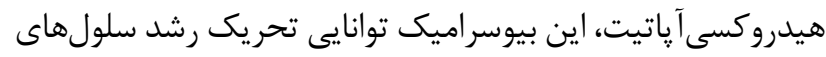
استخوان را به درون فضاى متخلخل خود دارد و در نتيجه باعث بانث تمايز و رشد سلولهاى استخوانى مىشود. لذا اين ماده در مهندسى دانى

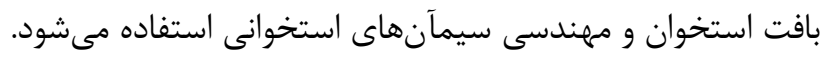

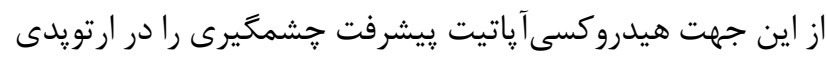
و يوشش دهى ايميلنت و وييوندهاى استخوانى سبب شده است.

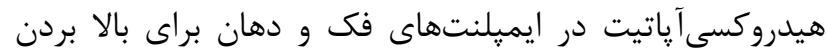

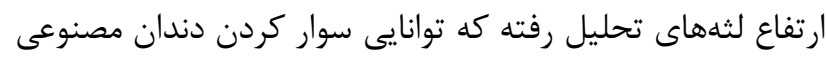

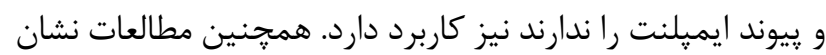

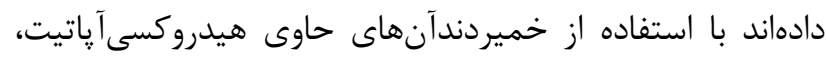
يوسيدگى ميناى دندان تا حدودى قابل بازسازى است. از آنجايى آناديى

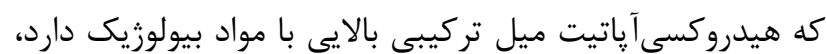

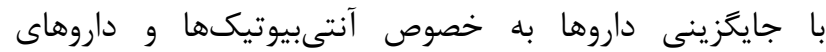
سركوبكنندهُ سيستم ايمنى، درون ايميلنتهاى يوشش داده شده

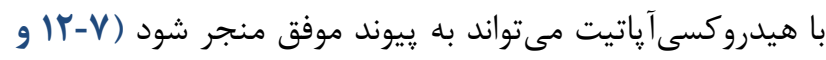

كاربرد غير :زشكى: تغليظ باكترىها (سا)، حذف فلزات

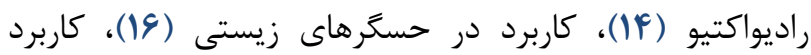
هيدروكسى آياتيت بهعنوان كاتاليست (IV).

\section{ץ- - روشهاى سنتز هيدروكسى آياتيت}

احر جه در سالهاى اخير تركيبات كلسيم فسفاتى كاربردهاى بسيارى دارند اما همجنان روشهاى توليد آنها براى دستيابى به

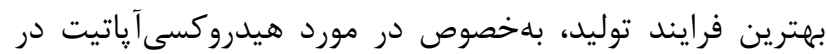
دست تحقيق است. روشهاى بسيار متعددى بلهورت شيميايى و

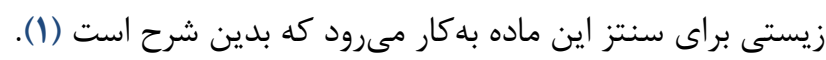

\section{ץ- إ- سنتز شيميايى هيدروكسى آياتيت}

امروزه روشهاى شيميايى متنوعى بلمنظور توليد

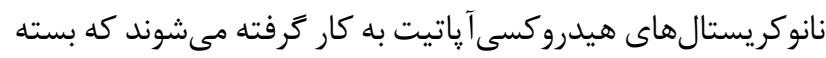

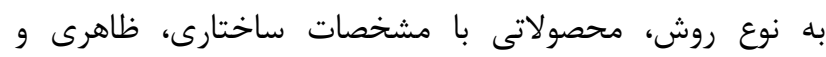

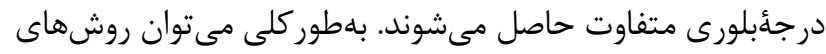

همجنين لازم به ذكر است كه اين تحقيق بر پايه مقالات جاب شده از نويسندكان مسئول، دكتر كيتى امتيازى و دكتر رسول روغنيان تدوين

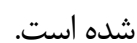

بافنها.

\section{1- خواص و كريستالوكرافى هيدروكسى آياتيت}

خانواده آياتيتى با آرايش منشور شش گوش با وجوه متوازى الاضلاع متبلور مىشود. هيدروكسى آياتيت نيز در حالت ايدئئال

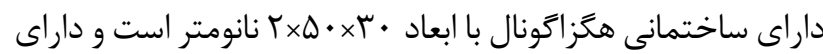

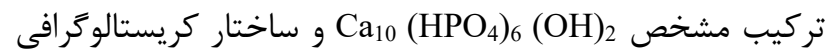
معين است. هيدروكسى آياتيت خالص با تركيب شيميايى ذكر شده داراى1/

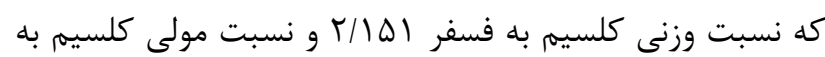

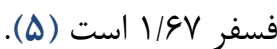

هيدروكسى آياتيت داراى سلول واحد يِيجيده و نسبتاً بزرگى

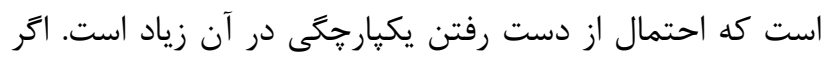

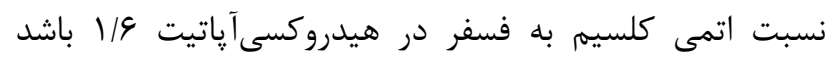

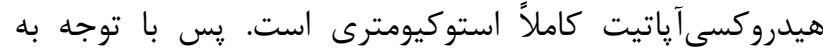

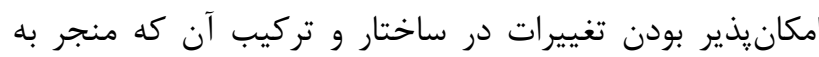

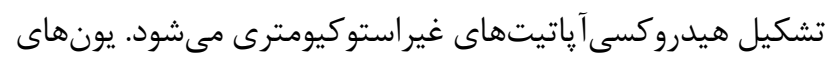

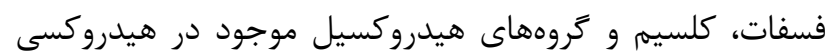
آياتيت مىتواند با يونهاى ديخر جايكزين شوند. اين تغييرات در

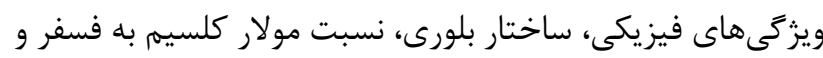

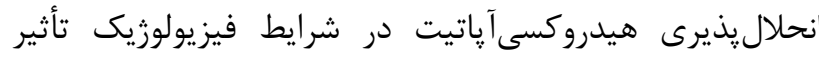

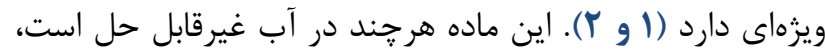

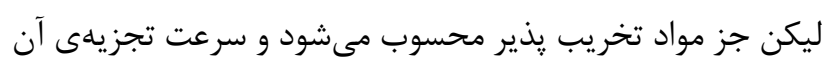
بسيار كم است (9).

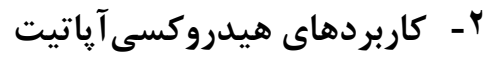

هيدروكسى يآتيت در زمينههاى مختلف يزشكى، دندانيزشكى، تشخيصى، كاتاليستى و تصفيه فاضلاب كاربرد دارد كه ذئه

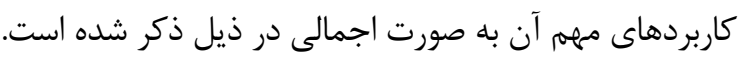
كاربرد هاى :زشكى: كاربرد مستقيم در ارتويدى (V))،

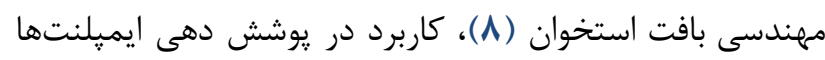
(9)، اثر ضد باكتريايى (•()، كاربرد در سيستمهاى رهايش دارو'

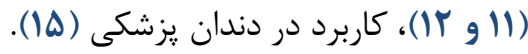


تميليت يا مايسلها' ، تكنيك رسوبگيرى شيميايى`، روش تهيه

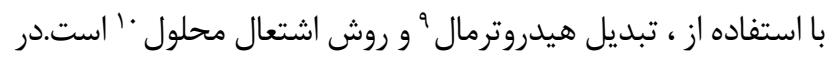
اين روشها معمولا از نمكهاى محلول مانند نيترات و كلريد كلسيه،

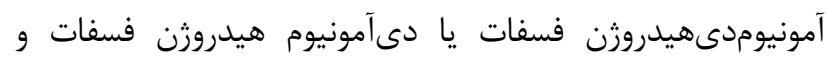

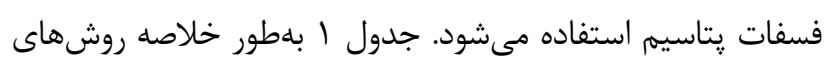
سنتز شيميايى هيدروكسى آياتيت را نمايش مى دهد. (ا و و9 (1).
شيميايى سنتز هيدروكسىآياتيت را به دو دسته روشهاى شيميايى تر و روشهاى سنتز خشك تقسيم كرد (11). روشهاى سنتز خشك يا روشهاى سنتز مكانيكى بدون آب شامل واكنش

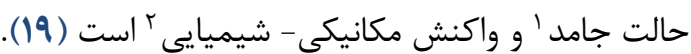

با در نظر داشتن مواد اوليه، واكنشهاى شيميايى تر شامل

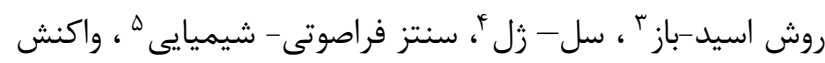

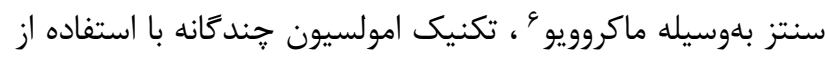

جدول ( ـ مقايسٔ روشهاى سنتز شيميايى هيدروكسى آياتيت ( (1، 1و 9 ().

\begin{tabular}{|c|c|c|c|c|c|c|}
\hline بلورينَّى درجه & شكل & ان اندازه & شر ايط و مكانيسم & مواد بيشنياز & روش رو & \\
\hline تقريبا بالا & متنوع & $\begin{array}{l}\text { ب. بيشتر ار } \\
\text { nm }\end{array}$ & دماى بالاى c . . 1. & $\begin{array}{c}\mathrm{CaCO}_{3} \\
\mathrm{CaHPO}_{4} \cdot 2 \mathrm{H}_{2} \mathrm{O}\end{array}$ & حالت جامد & \multirow{2}{*}{ سنتز خشك } \\
\hline تقريبا بالا & متنوع & بيشتر از • ب ب nm & $\begin{array}{l}\text { آسياب با دور بالاى . . } \\
\text { rmpsmp }\end{array}$ & $\begin{array}{c}\mathrm{CaO} \\
\mathrm{CaHPO}_{4}\end{array}$ & مكانيكى -شيميايى & \\
\hline هايين & 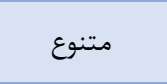 & محدوده ميكرون & واكنش ميان اسيد و باز & $\begin{array}{c}\mathrm{Ca}(\mathrm{OH})_{2} \\
\mathrm{H}_{3} \mathrm{PO}_{4}\end{array}$ & اسيد-باز & \multirow{8}{*}{ سنتز تر } \\
\hline تقريبا بالا & عموما كروى & محدوده نانو & كلسيم و فسفر در & $\begin{array}{c}\text { Urea } \\
\text { EDTA } \\
\mathrm{Ca}\left(\mathrm{NO}_{3}\right)_{2} \\
\mathrm{NH}_{2} \mathrm{PO}_{4}\end{array}$ & 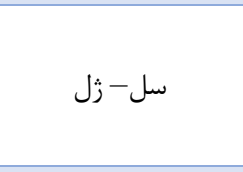 & \\
\hline تقريبا پايين & عموما سوزنى & ن انو و ميكرون & 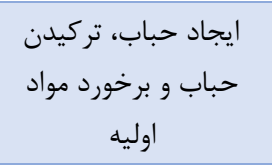 & $\begin{array}{c}\mathrm{Ca}(\mathrm{OH})_{2} \\
\mathrm{H}_{3} \mathrm{PO}_{4} \\
\mathrm{Ca}\left(\mathrm{CH}_{3} \mathrm{CO}\right)_{2} \\
\mathrm{PO}(\mathrm{OCH} 3)_{3}\end{array}$ & فراصوتى - شيميايى & \\
\hline تقريبا يايين & متنوع & ميكرون & حرارت و تابش امواج & $\begin{array}{c}\mathrm{Ca} \\
\mathrm{PO}_{4}\end{array}$ & ماكروويو & \\
\hline تقريبا يايين & عموما كروى & ن انو و ميكرون & 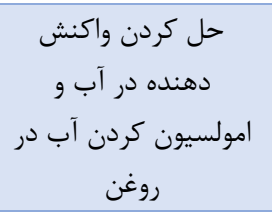 & $\begin{array}{c}\mathrm{Ca} \\
\mathrm{PO}_{4}\end{array}$ & امولسيون خند & \\
\hline هايين & متنوع & ميكرون & رسوب گيرى & $\begin{array}{c}\mathrm{Ca}\left(\mathrm{NO}_{3}\right)_{2} \\
\left(\mathrm{NH}_{4}\right)_{3} \mathrm{HPO}_{4}\end{array}$ & رسوب گيرى شيميايى & \\
\hline تقريبا هايين & متنوع (عموما & ميكرون & فشار بالا، دماى بالا & $\begin{array}{c}\mathrm{Ca} \\
\mathrm{PO}_{4}\end{array}$ & تبديل هيدروترمال & \\
\hline تقريبا يايين & $\begin{array}{l}\text { ستنوع (عموما } \\
\text { سوزنى) }\end{array}$ & نانو و ميكرون & افزودن عوامل اكساينده & $\begin{array}{l}\mathrm{NH}_{2} \mathrm{PO}_{4} \\
\mathrm{Ca}\left(\mathrm{NO}_{3}\right)_{2}\end{array}$ & اشتعال محلول & \\
\hline
\end{tabular}

تشكيل كريستالها استفاده مىشود. اين درحالى است كه درجه حرارت مورد نياز براى عمليات تشكيل هيدروكسى آياتيت در روش هرئي سل-زل بسيار رايينتر است. از نظر هزينه نسبت به سايرين مقرون به صرفهتر است و در قياس با محصولات ساير روشها،

${ }^{6}$ Microwave-assisted synthesis

${ }^{7}$ Multiple emulsion technique

${ }^{8}$ Precipitation technique

${ }^{9}$ Hydrothermal conversion

${ }^{10}$ Solution combustion method
بنابر يافتههاى Hsieh و همكاران روش سل زل داراى مزايايى نسبت به ساير روشهاى شيميايى ليست شده در جدول ا هست. اين روش در مقايسه با ساير روشها به تيمار دمايى يايين نياز دارد.

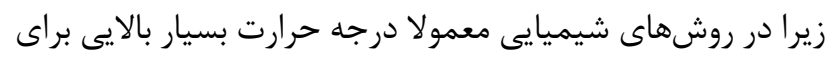




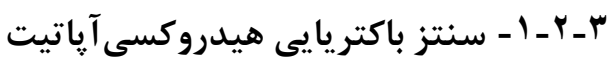

همانكونه كه بِيش از اين امتيازى و همكاران ثابت كردند كه

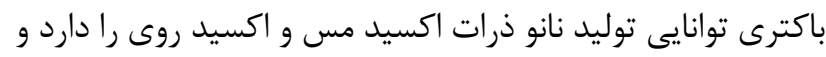

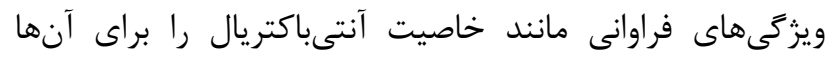

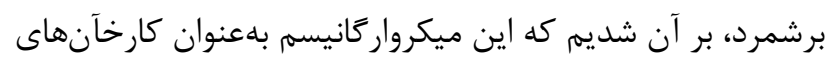

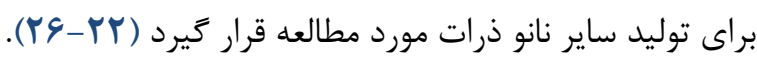
از جمله روشهاى جديد سنتز هيدروكسى آياتيت نانومترى

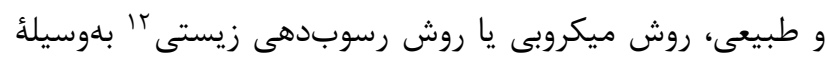

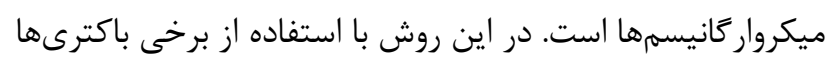

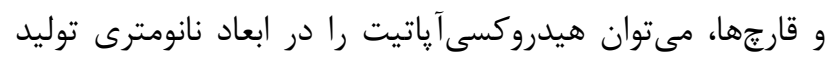

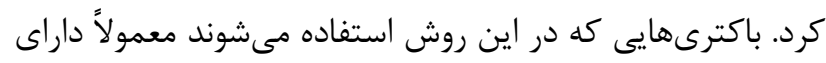

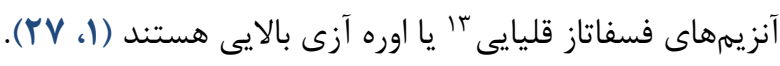

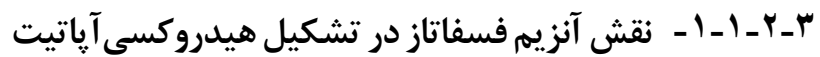

در فرايند استخوان سازى، رسوبدهى زيستى يروسهاى است

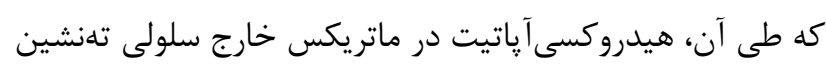

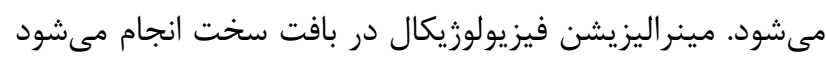

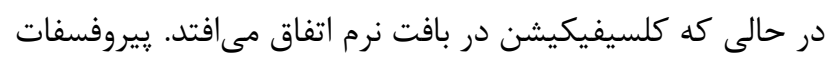
توسط آلكالين فسفاتاز غير اختصاصى بافت(TNAP

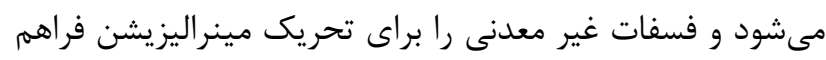

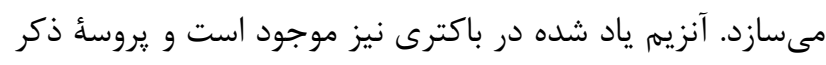

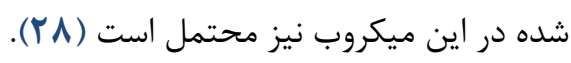

بلمطور كلى دو نوع آنزيم فسفاتاز در ميكروار كانيسمها وجود

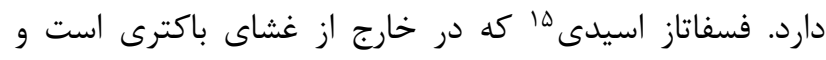

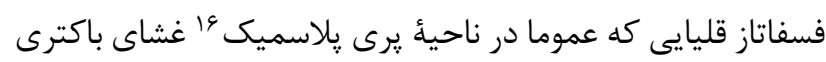

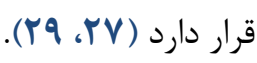

با استفاده از آنزيمهاى فسفاتاز اسيدى مىتوان هيدروكسى إنى

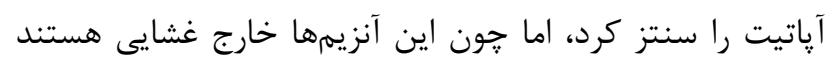

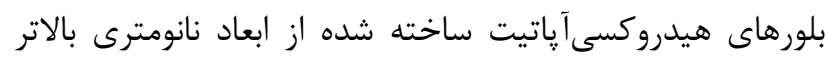

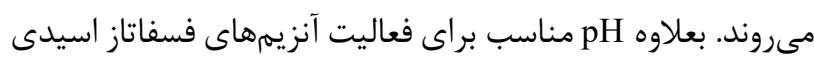

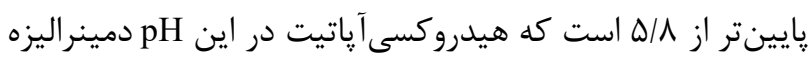

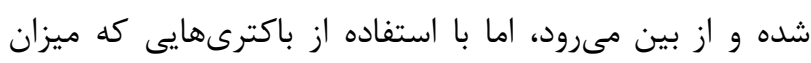

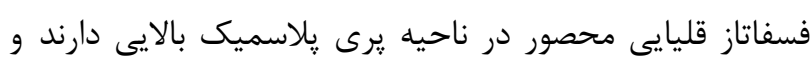

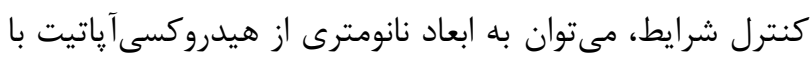

${ }^{15}$ Acid phosphatase

${ }^{16}$ Preplasmic aeria
هيدروكسى آياتيتهاى سنتزشده از اين روش يك شكلى بيشترى

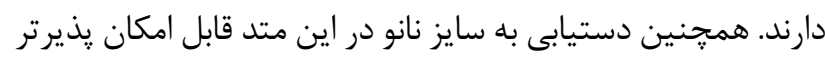

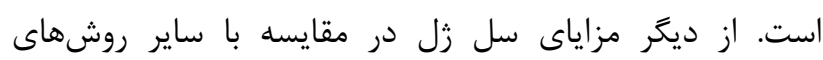

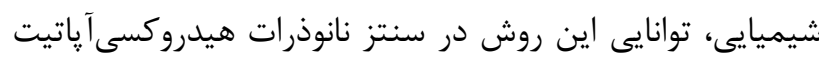

با درجه خلوص تقريبا بالاترى است (•) أF).

\section{r-r - - سنتز بيولوزيك هيدروكسى آياتيت}

بافت استخوانى اغلب يستانداران، ماكيان و ماهىها يكى از

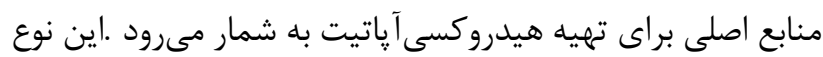

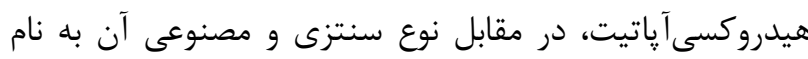

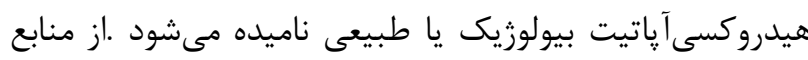

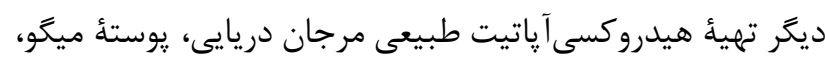

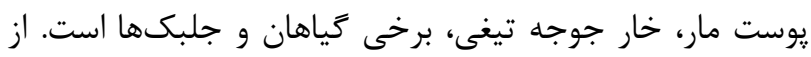

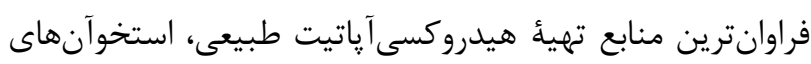

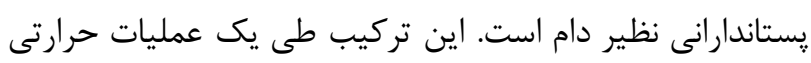

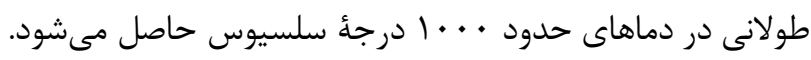

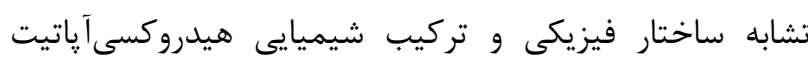

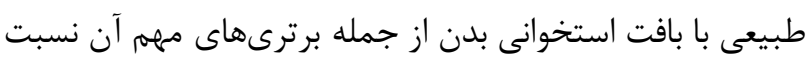

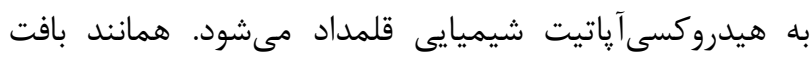

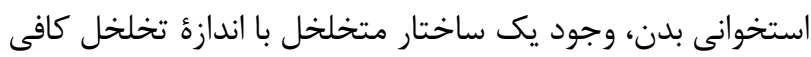

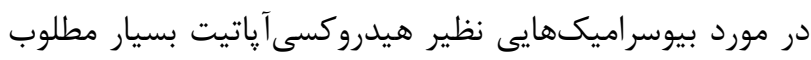

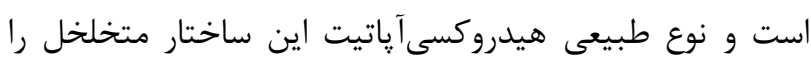

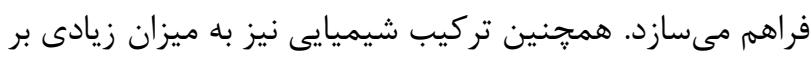

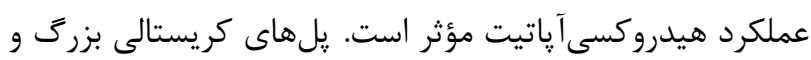

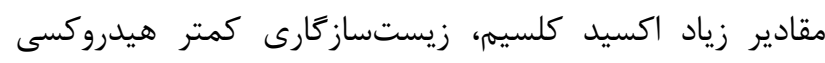

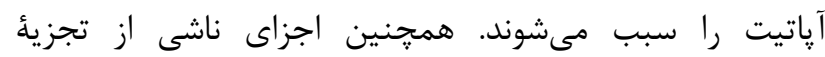

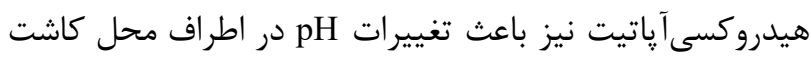

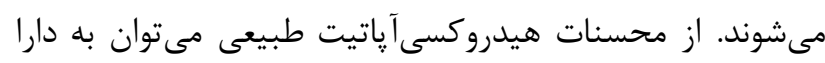

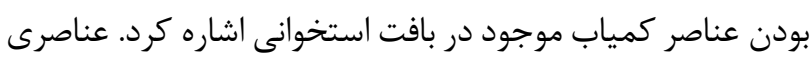

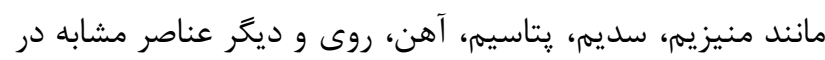

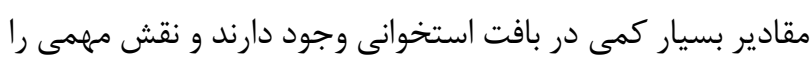

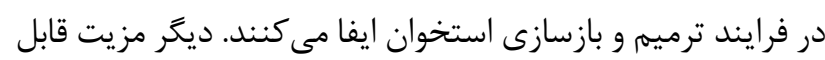

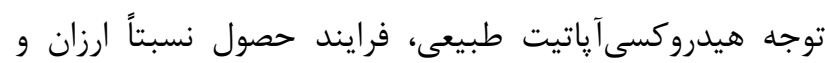

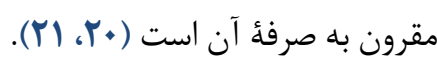

\footnotetext{
${ }^{12}$ Biomineralization

${ }^{13}$ Alkaline phosphatase (ALP)

${ }^{14}$ Tissue nonspecific alkaline phosphatase
} 


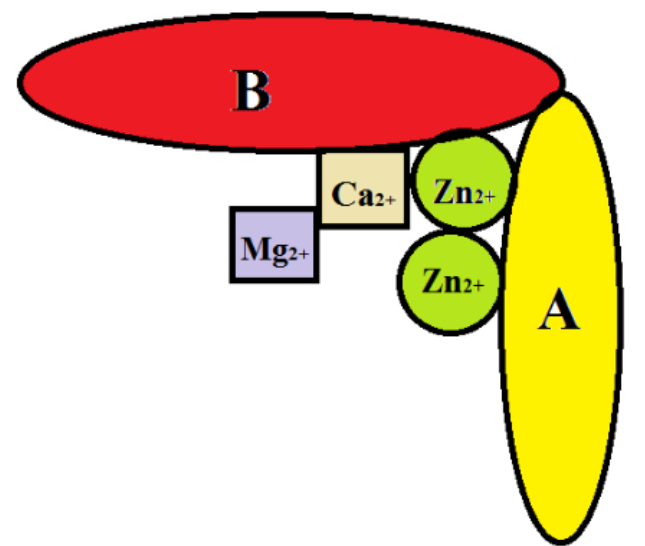

شكل ا. تصوير شماتيك متالوانزيم فسفاتاز قليايى. A و B: زنجيره

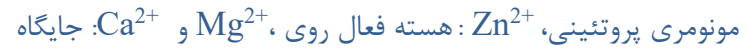
كوفاكتورى براى منيزيم و كلسيم. (منبع: نويسندًان)

pH ويزگ هاى زيست سازكارى و زيست فعالى رسيد. همجنين بهينه براى فعاليت آنزيمهاى فسفاتاز قليايى 9 است (F و •بائ). تمامى آنزيمهاى فسفاتاز قليايى از گروه آنزيمهاى هيدرولاز

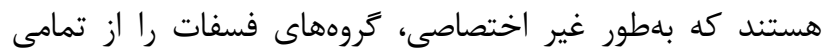

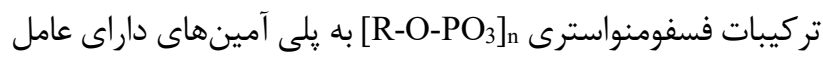

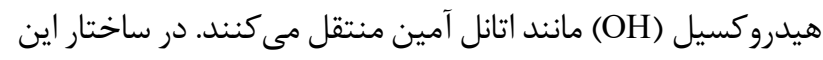
متالوآنزيمها، دو زنجيره مونومرى يروتئينى، دو هسته فعال روى و و ماندين دو جايگاه كوفاكتورى براى منيزيم و كلسيم وجود دارد (شكل ().

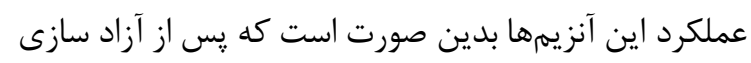

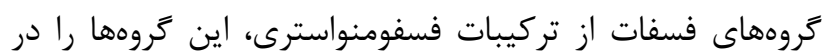
فضاى محدود يرى يلاسميك، در اختيار عوامل هيدروكسى (OH)

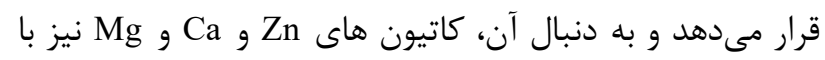

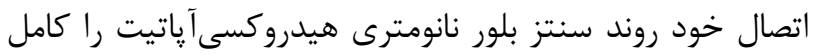
مى كنند (شكل r)، (اس و • (r).
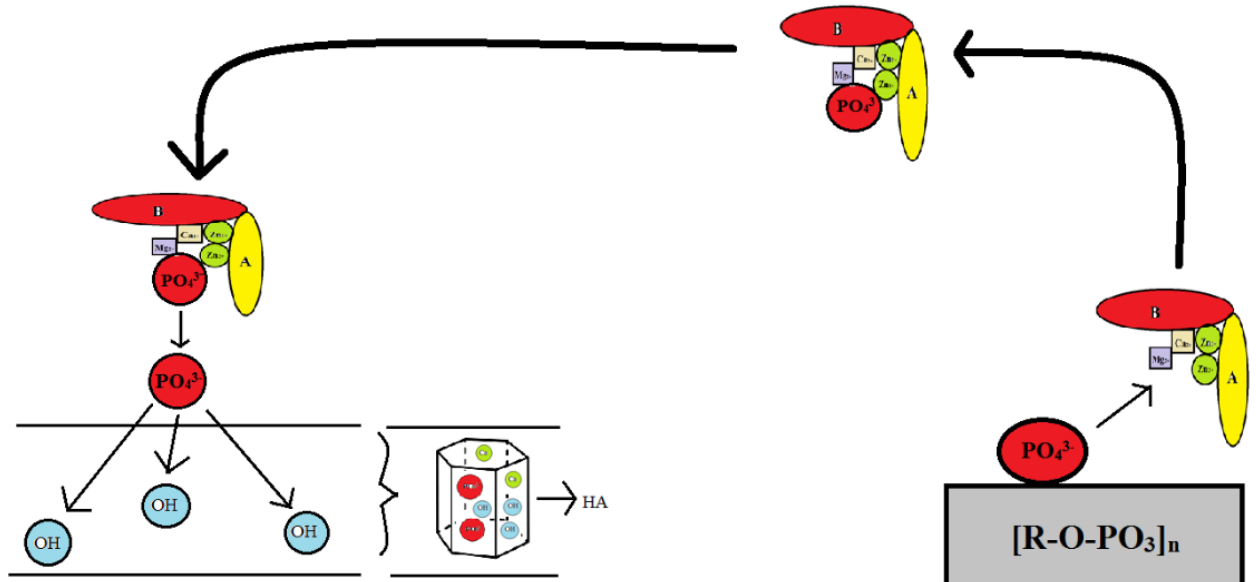

شكل r. روند مورد انتظار تشكيل كريستالهاى هيدروكسىآياتيت (HA) در باكترى و نقش آنزيمم فسفاتاز قليايى در اين فرايند. (منبع: نويسندًان)

بلهوسيلة يك مولكول القاء كننده مثل اوره يا شرايط محيطى ديكر

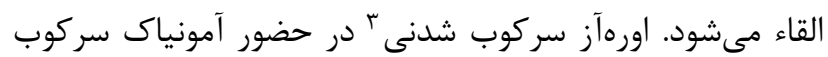

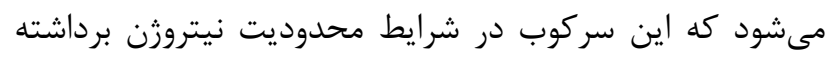

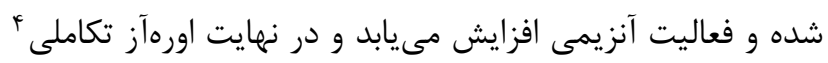

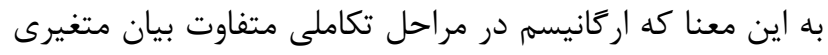

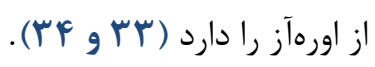

${ }^{3}$ Repressible

${ }^{4}$ Developmental

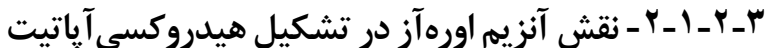
آنزيم اورهآز به صورت گسترده در ميان باكترىها ديده

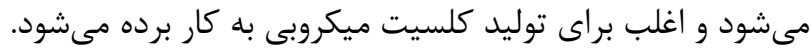
جهار مدل تنظيمى براى سنتز آنزيم اورهآز در سيستم

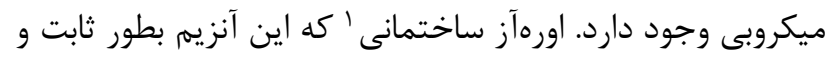

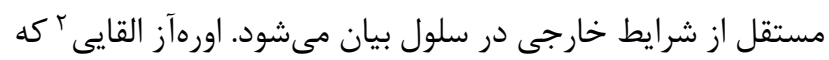

${ }^{1}$ Constitutive

${ }^{2}$ Inducible 
ساختار بلورى ذرات هيدروكسى آياتيت وارد شوند. بنابراين نوعى كئ

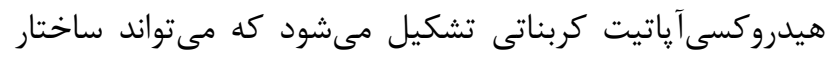

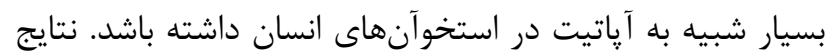

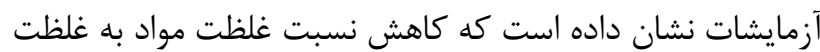

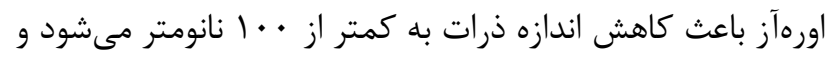

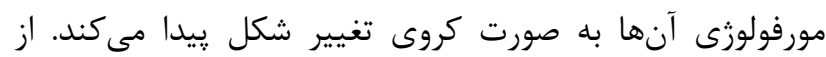

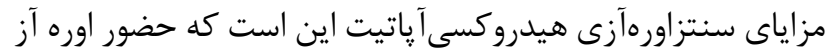

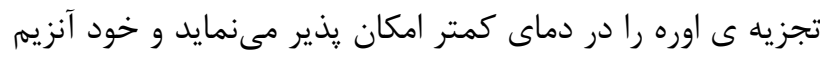

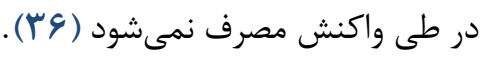

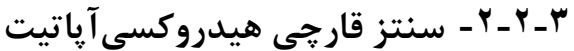

در نتايج آزمايشات مربوط هيدروكسى آياتيت، مشاهده شده

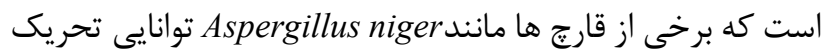

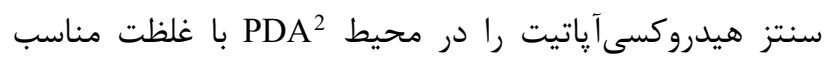
موادى مانند ${ }^{2} \mathrm{Na}_{2} \mathrm{HPO}_{4}$ كريستالهاى هيدروكسى آياتيت به شرح زير است. متابوليسم

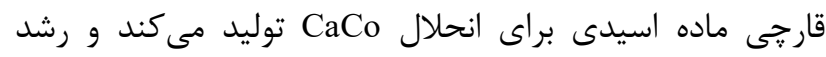

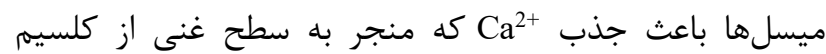

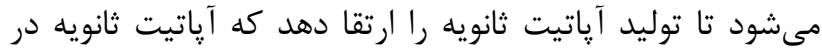

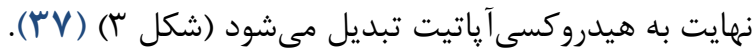

اغلب ميكروار كانيسمها با توانايى تجزيه اوره، از آن بلعنوان يك منبع نيتروزن استفاده مى كنند كه بهوسيلة انتقال فعال يا

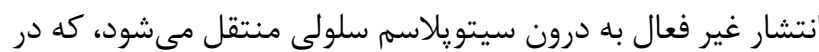

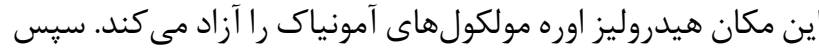

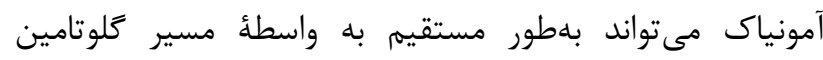

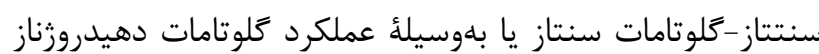
جذب بيومس شود. يك ميكرواركانيسم ايدهآل براى سيمانكارى زيستى' بايد به غلظتهاى بالاى اوره و كلسيم مقاوم باشد. اين

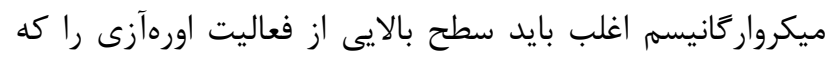

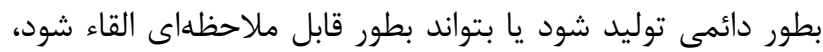

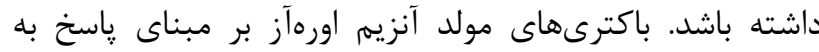

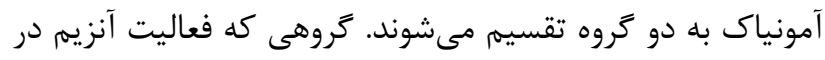

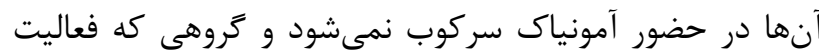

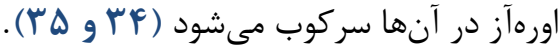

در سنتز اورهآزى هيدروكسى آياتيت مقادير مختلفى از

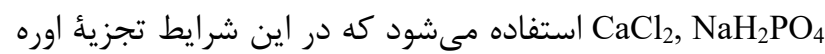

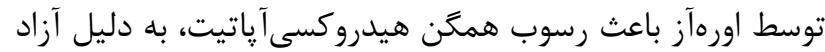
شدن يون OH در طول فرايند هيدروليز اوره، مىشود. همجنين هيدين

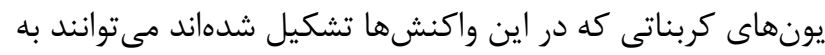

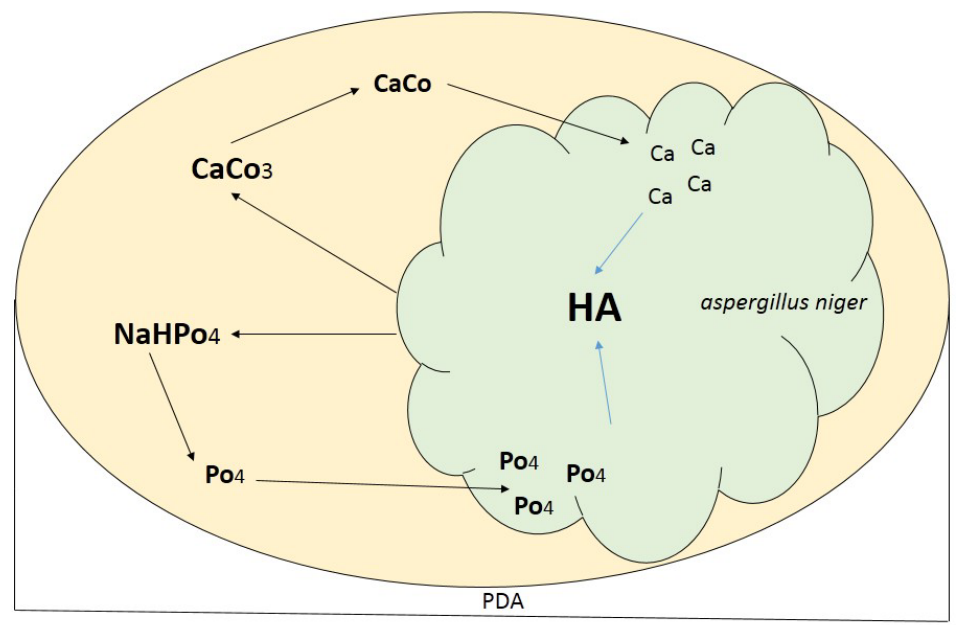

شكل ऍّ. روند يِش بينى شده براى تشكيل هيدروكسى آياتيت در مايسل و هيف قارجى (منبع: نويسندكان)

مىشود. با استفاده از آنزيم فيتاز خارج سلولى توليدشده توسط تخمير سبوس كندم با قارج مذكور اين واكنش صورت مى ئيرد. فيتاز يك كلاس از فسفوهيدرولاز هاست كه هيدروليز Phytic acid به مونوفسفات معدنى را كاتاليز مى كند. در نهايت به مخلوط قارج

2 Potato dextrose agar
در روشى ديخر با استفاده از قارج Aspergillus niger و سبوس كَندم بلعنوان منبع فسفر هيدروكسى آياتيت سنتز شده است. سبوس گندم داراى مقدار قابل توجهى فسفر (به فرم Phytic

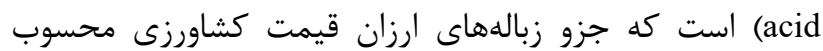

${ }^{1}$ Biocementation 
با توجه به مقرون به صرفه بودن روش ميكروبى و كيفيت

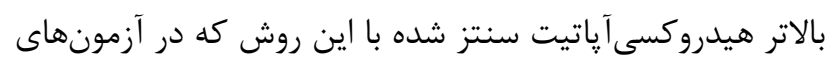

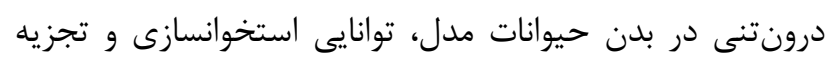

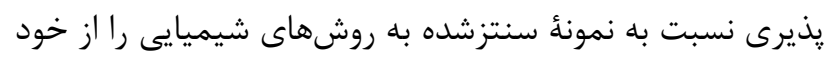

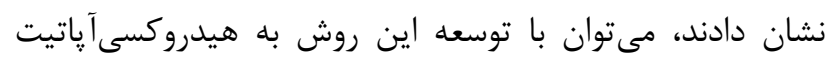

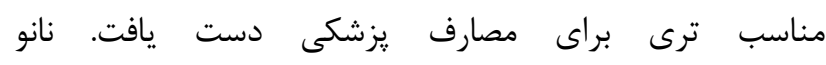

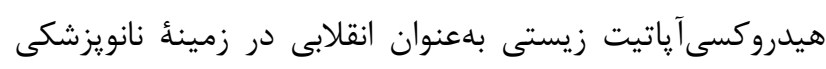

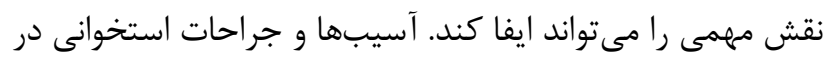

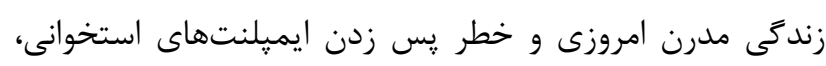

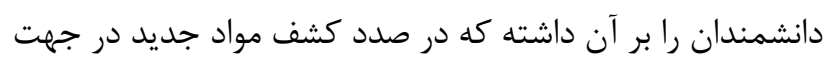

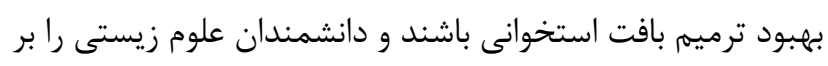

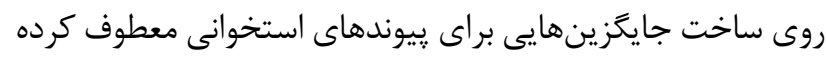

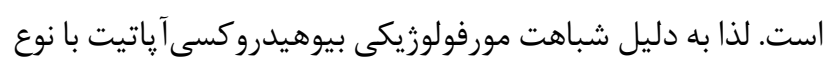
طبيعى و استخوانى آن و شباهت ابعادى آن (در مقياس نانو)، كاربرد

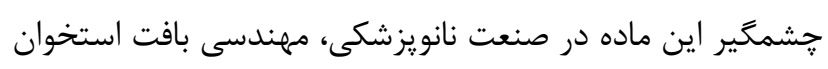

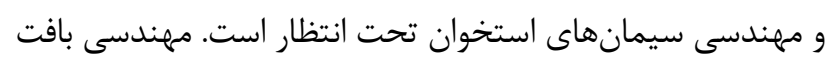

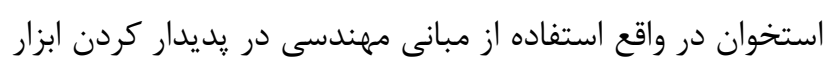

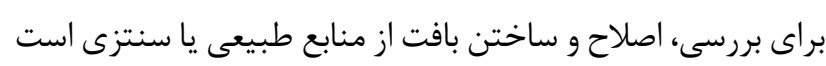

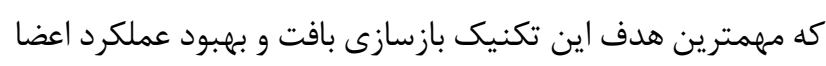

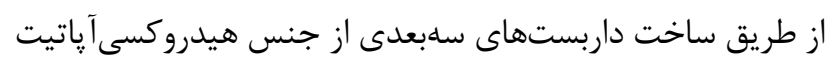

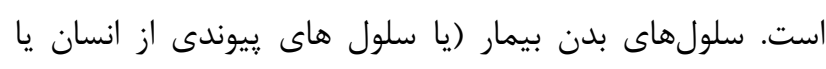

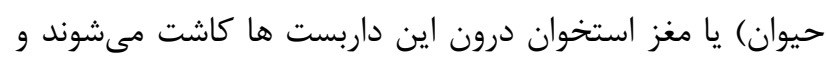

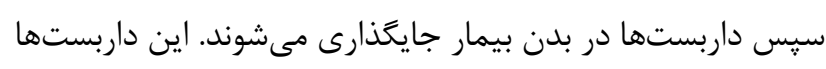

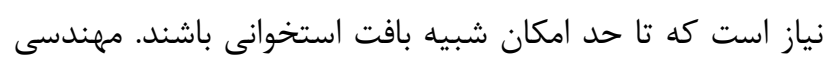

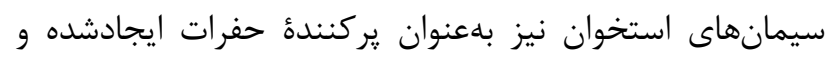

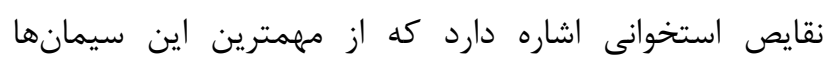

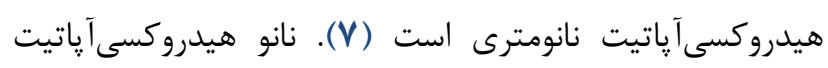

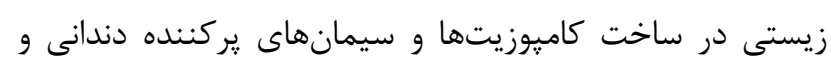

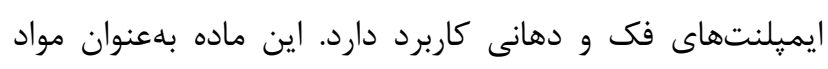

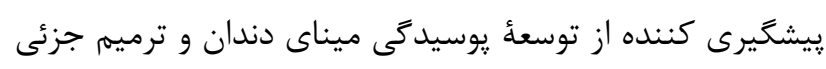

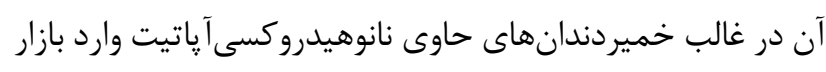

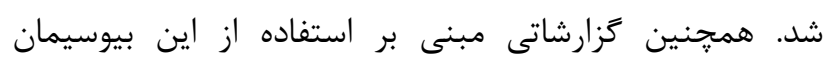

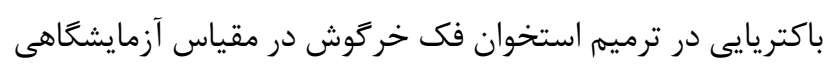

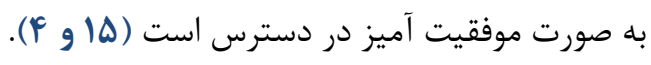

سياسگزارى ندارد.
و سبوس گَندم كه تخمير در آنها صورت گرفته است كلريد

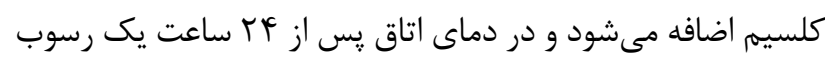

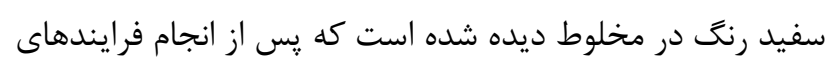

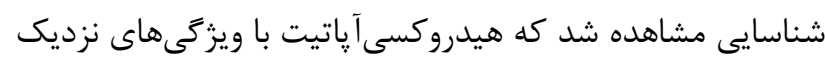

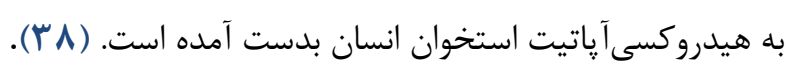

\section{بحث}

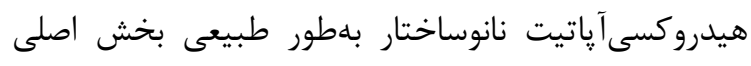

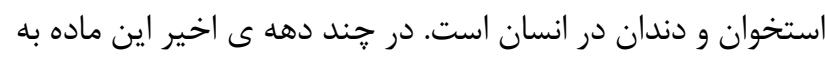

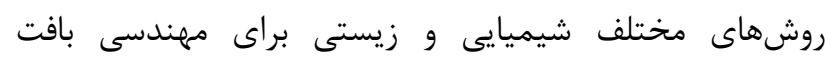

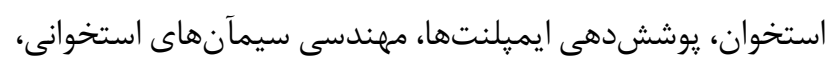

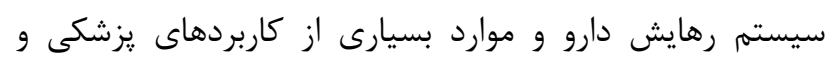

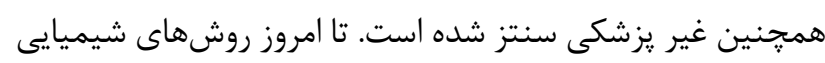

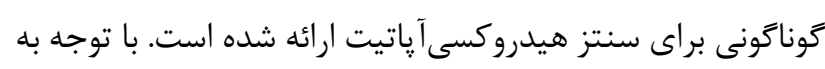

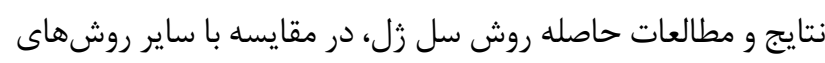

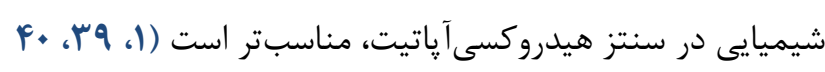

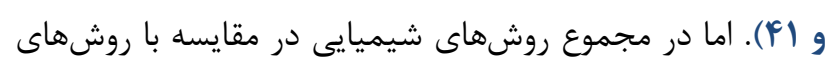

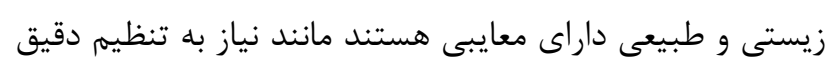

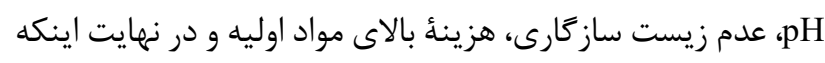

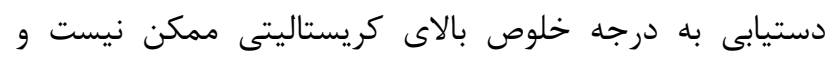

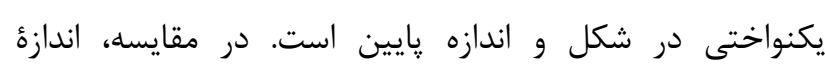

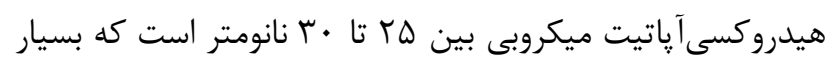

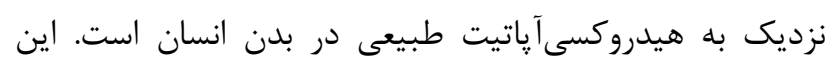

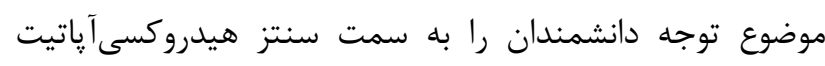

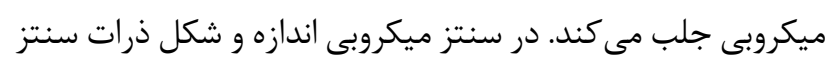

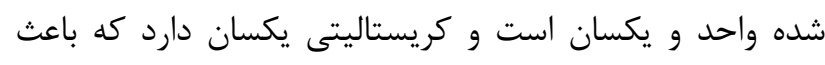

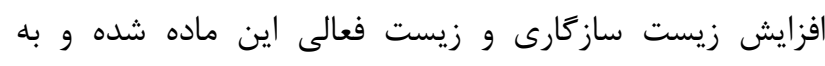

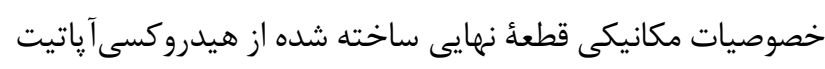

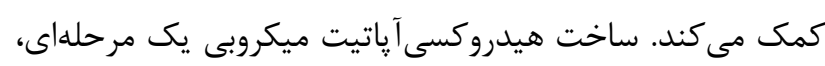

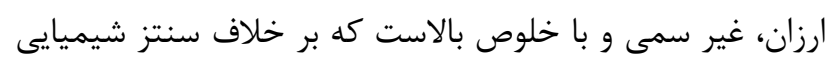

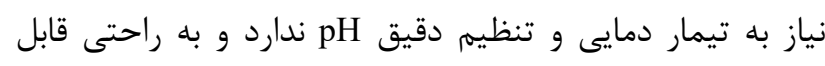

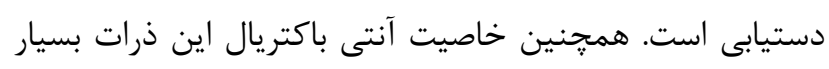

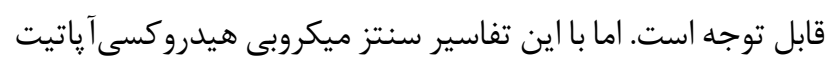

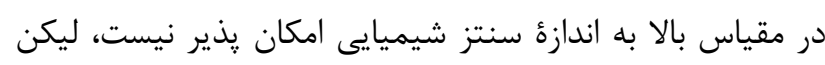
تمايز سلولهاى استخوانى به مقدار بالايى هيدروكسى آياتيت نياز

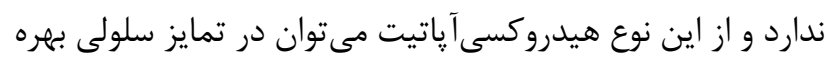

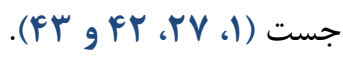




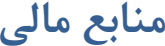

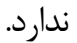

$$
\begin{aligned}
& \text { نويسندگان هيج گونه تعارضى در منافع گزارش نكرده اند. }
\end{aligned}
$$

\section{Referance}

1. Emtiazi G, Shapoorabadi FA, Mirbagheri M. Chemical and Biological Synthesis of HydroxyApatite: Advantage and Application. Int J Microbiol Curr Res 2019; 1(1):20-2. [DOI:10.18689/ijmr-1000103]

2. Wang L, Nancollas GH. Calcium orthophosphates: crystallization and dissolution. Chem Rev. 2008; 108(11):4628-69. [DOI:10.1021/cr0782574] [PMID] [PMCID]

3. Kumar RR, Wang M. Functionally graded bioactive coatings of hydroxyapatite/titanium oxide composite system. Mater Lett .2002; 55(3):133-7. [DOI:10.1016/S0167577X(01)00635-8]

4. Ahmadzadeh E, Talebnia F, Tabatabaei M, Ahmadzadeh H, Mostaghaci B. Osteoconductive composite graft based on bacterial synthesized hydroxyapatite nanoparticles doped with different ions: from synthesis to in vivo studies. Nanomed Nanotechnol Biol Med. 2016; 12(1):1387-95. [DOI:10.1016/j.nano.2016.01.020] [PMID]

5. Chopra Y, Kumar R, Begam H. Effect of Temperature and Titania Doping on Structure of Hydroxyapatite. In: Rizvanov AA, Singh BK, Ganasala P. Advances in Biomedical Engineering and Technology. Lecture Notes in Bioengineering. Singapore: Springer;2021. [DOI:10.1007/978-981-15-6329-4 24] [PMCID]

6. Corno M, Busco C, Bolis V, Tosoni S, Ugliengo P.Water adsorption on the stoichiometric (001) and (010) surfaces of hydroxyapatite: a periodic B3LYP study. Langmuir. 2009; 25(4):2188-98. [DOI:10.1021/la803253k] [PMID]

7. Benaqqaa C, Chevaliera J, Daouia MS, Fantozzi G. Slow crack growth behavior of hydroxyapatite ceramics. Biomaterials. $2005 ; \quad 26(31): 6106-12$. [DOI:10.1016/i.biomaterials.2005.03.031] [PMID]

8. Padmanabhan SK, Gervaso F, Sannino A, Licciulli A. Preparation and characterization of Collagen/hydroxyapatite microsphere composite scaffold for bone regeneration. Key Eng Mater. 2014; 587(1-3):239-44. [DOI:10.4028/www.scientific.net/KEM.587.239]

9. Babu NR, Manwatkar S, Rao KP, Kumar TSS. Bioactive coatings on 316L stainless steel implants. Trends Biomater Artif Organs. 2004; 17(2):43-7.

10. Tin-Oo MM, Gopalakrishnan V, Samsuddin AR, Al Salihi KA, Shamsuria O. Antibacterial property of locally produced hydroxyapatite. Arch Orofac Sci .2007; 2:41-4.

11. Assadi z, Emtiazi G, Zarrabi A. Hyperbranched polyglycerol coated on copper oxide nanoparticles as a novel core-shell nano-carrier hydrophilic drug delivery model. J Mol Liq. 2018; 250(1):375-80. [DOI:10.1016/j.molliq.2017.12.031]

12. Palazzoa B, Sidotia TMC, Roveria N, Tampierib A, Sandrib M, Bertolazzic L, et.al. Controlled drug delivery from porous hydroxyapatite grafts: An experimental and theoretical approach. Mater Sci Eng C. 2005; 25(2):207-13. [DOI:10.1016/j.msec.2005.01.011]
13. Berry ED, Siragusa GR. Hydroxyapatite adherence as a means to concentrate bacteria. Appl Environ Microbiol. 1997; 6(1):4069-74. [DOI:10.1128/aem.63.10.40694074.1997] [PMID] [PMCID]

14. Handley-Sidhu S, Renshaw JC, Yong P, Kerley R, Macaskie LE. Nano-crystalline hydroxyapatite bio-mineral for the treatment of strontium from aqueous solutions. Biotechnol Lett. 2011; 33:79-87. [DOI:10.1007/s10529-010-0391-9] [PMID]

15. Tschoppe P, Zandim D L, Martus P, Kielbassa AM. Enamel and dentine remineralization by nano-hydroxyapatite. $\mathrm{J}$ Dent. 2011; 39(6): 430-7. [DOI:10.1016/i.jdent.2011.03.008] [PMID]

16. Wang S, Lei $\mathrm{Y}$, Zhang $\mathrm{Y}$, Tang J, Shen G, Yu R. Hydroxyapatite nanoarray-based cyanide biosensor. Anal Biochem. 2010; [DOI:10.1016/j.ab.2009.11.029] [PMID]

17. Tsuchida T, Yoshioka T, Sakama S, Takeguchi T, Ueda W. Synthesis of Biogasoline from Ethanol over Hydroxyapatite Catalyst. Ind Eng Chem Res. 2008; 47(1):1443-52. [DOI:10.1021/ie0711731]

18. Rhee SH. Synthesis of hydroxyapatite via mechanochemical treatment. Biomaterials. 2002; 23(4):1147-52. [DOI:10.1016/S0142-9612(01)00229-0]

19. Shojai MS, Khorasani MT, Dinpanah-Khoshdargi E, Jamshidi A. Synthesis methods for nanosized hydroxyapatite with diverse structures. Acta Biomater. 2013; 9(8):7591-621. [DOI:10.1016/j.actbio.2013.04.012] [PMID]

20. Rahavi SS, Ghaderi O, Monshi, Fathi MH. A comparative study on physicochemical properties of hydroxyapatite powders derived from natural and synthetic sources. Russ J Non-ferrous Metals. 2017; 58: 276-86. [DOI: 10.3103/S1067821217030178]

21. Ruksudjarit A, Pengpat K, Rujijanagul G, Tunkasiri T. Synthesis and characterization of nanocrystalline hydroxyapatite from natural bovine bone. Curr Appl Phys. 2008; 8:270-2. [DOI:10.1016/j.cap.2007.10.076]

22. Assadi z, Emtiazi G, Zarrabi A. Novel synergistic activities of tetracycline copper oxide nanoparticles integrated into chitosan micro particles for delivery against multiple drug resistant strains: Generation of reactive oxygen species (ROS) and cell death. J Drug Deliv Sci Technol. 2018; 44(1):65-70. [DOI:10.1016/j.jddst.2017.11.017]

23. Assadi z, Emtiazi G, Zarrabi A. Opto-electronic and antibacterial activity investigations of mono-dispersed nanostructure copper oxide prepared by a novel method: reduction of reactive oxygen species (ROS). J Mater Sci Mater. 2018; 29(3):1798-807. [DOI:10.1007/s10854-0178088-7]

24. Mirhendi M, Emtiazi G, Roghanian R. Production of nano zinc, zinc sulphide and nanocomplex of magnetite zinc oxide by Brevundimonas diminuta and Pseudomonas stutzeri. IET 
Nanobiotechnol. 2013; 7(4):135-9. [DOI:10.1049/ietnbt.2012.0032] [PMID]

25. Mirhendi M, Emtiazi G, Roghanian R. Antibacterial Activities of Nano Magnetite $\mathrm{ZnO}$ Produced in Aerobic and Anaerobic Condition by Pseudomonas stutzeri. Jundishapur J Microbiol. 2013; 6(10): e10254. [DOI:10.5812/jim.10254]

26. Soltani Nezhad S, Rabbani Khorasgani M, Emtiazi G, Yaghoobi MM, Shakeri Sh. Isolation of copper oxide $(\mathrm{CuO})$ nanoparticles resistant Pseudomonas strains from soil and investigation on possible mechanism for resistance. World $\mathrm{J}$ Microbiol Biotechnol. 2014; 30:809-17. [DOI:10.1007/s11274-013-1481-3] [PMID]

27. Emtiazi G. Microbial enzymes induced nano-hydroxyapatite and calcite precipitation. DBpia korean confrancce. 2017; 26.

28. Orimo $\mathrm{H}$. The mechanism of mineralization and the role of alkaline phosphatase in health and disease. J Nippon Med Sch. 2010; 77:4-12. [DOI:10.1272/jnms.77.4] [PMID]

29. Ghashghaei S, Emtiazi G. Production of hydroxyapatite nanoparticles using tricalcium- phosphate by alkanindiges illinoisensis. J Nanomater Mol Nanotechnol. 2013; 2:5. [DOI:10.4172/2324-8777.1000121]

30. Ledo H M, Thackray AC, Jones IP, Marquis PM, Macaskie LE, Sammons RL. Microstructure and composition of biosynthetically synthesized hydroxyapatite. J Mater Sci Mate Med. 2008; 19(11):3419-27. [DOI:10.1007/s10856008-3485-3] [PMID]

31. Kim EE, Wyckoff HW. Reaction mechanism of alkaline phosphatase based on crystal structures. Two-metal ion catalysis. J Mol Biol. 1991; 218(2):449-64. [DOI:10.1016/0022-2836(91)90724-K]

32. Mostaghaci B, Fathi MH, SheikhZeinoddin M, Soleimanianzad S. Bacterial synthesis of nanostructured hydroxyapatite using Serratia marcescens PTCC1187, Int J Nanotechnol. 2009; 6:1015-30. [DOI:10.1504/IJNT.2009.027564]

33. Fujita Y, Ferris FG, Lawson RD, Colwell FS, Smith RW. Calcium carbonate precipitation by ureolytic subsurface bacteria. Geomicrobiol J .2000; 17:305-18. [DOI: 10.1080/782198884]
34. Ghashghaei S, Emtiazi G. Production of calcite nanocrystal by a urease-positive strain of Enterobacter ludwigii and study of its structure by SEM. Curr microbiol. 2013; 67(4):406-13. [DOI:10.1007/s00284-013-0379-5] [PMID]

35. Ghashghaei S, Emtiazi G. The Methods of Nanoparticle Synthesis Using Bacteria as Biological Nanofactories, their Mechanisms and Major Applications. Curr Bionanotechnol. 2016; 1(1):3-17. [DOI:10.2174/2213529401999140310104655]

36. Jokic B, Tanaskovic D, Jankovic-Castvan I, Drmanic S, Petrovic R. Synthesis of nanosized calcium hydroxyapatite particles by the catalytic decomposition of urea with urease. J Mater Res. 2006; 22(5):1156-61. [DOI:10.1557/jmr.2007.0170]

37. He F, Lian B, Liu SR, Gong GH. Induced synthesis of hydroxyapatite by Aspergillus niger. Wei Sheng Wu Xue Bao. 2011. 51(3):417-22.

38. Soni SK. Phytase from Aspergillus niger NCIM 563: Isolation Purification, Characterization and its Applications [PhD thesis]. Maharashtra India: univ. Pune; 2009.

39. Gupta R, Mozumdar S, Chaudhury NK. Effect of ethanol variation on the internal environment of sol-gel bulk and thin films with aging. Biosens Bioelectron. 2005; 21(4):549-56. [DOI:10.1016/j.bios.2004.12.002] [PMID]

40. Hsieh M, Perng L, Chin T, Perng H. Phase purity of sol-gelderived hydroxyapatite ceramic. Biomaterials. 2001; 22(19): 2601-7. [DOI:10.1016/S0142-9612(00)00448-8]

41. Satta G, Pompei R, Grazi G, Cornaglia G. Phosphatase activity is a constant feature of all isolates of all major specice of the family Entrrobacteriaceae. J Clin Microbiol. 1988; 26(12): 2637-41. [DOI:10.1128/jcm.26.12.26372641.1988] [PMID] [PMCID]

42. Ganachari SV, Bevinakatti AA, Yaradoddi JS, Banapurmath NR, Hunashyal AM, Shettar AS. Rapid synthesis, characterization, and studies of hydroxyapatite nanoparticles. Adv Mater Sci Res .2017; 1:1-8.

43. Sassoni E. Hydroxyapatite and other calcium phosphates for the conservation of cultural heritage: A Review. Materials. 2018; 11(4):557. [DOI:10.3390/ma11040557] [PMID] [PMCID] 